\title{
Forestry - A Shared Responsibility L'aménagement forestier - une responsabilité partagée
}

\author{
Prince Albert, Saskatchewan \\ September 18-22, 1988 \\ le 18-22 septembre 1988
}

The Forestry Chronicle

Volume 64, Number 6, December 1988

Annual Meeting Supplement

\section{President's Report 1987-88}

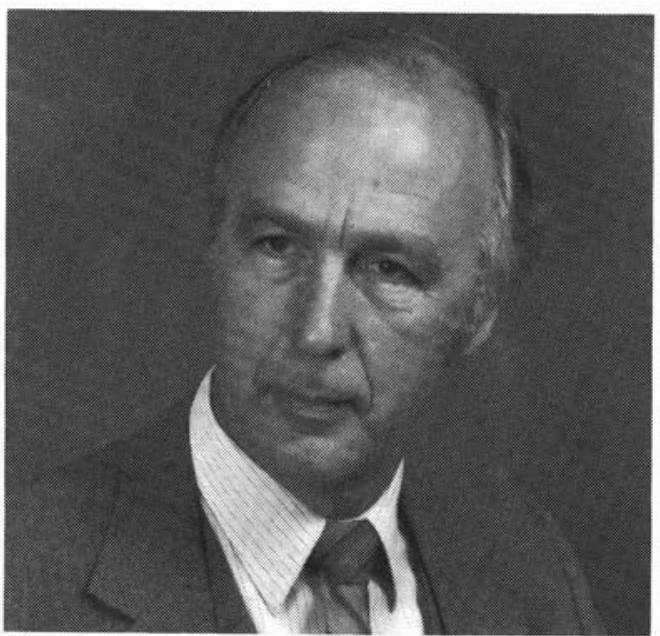

Before starting to write this report, I looked at some of the reports of our Past Presidents and I was impressed with the recurring theme that so much progress within our Institute is dependent on the unstinting contributions of so many of our members. Well, 1988 has not been an exception, and my concluding comments express my thanks.

Since the products of many of the meetings I attended are reported more fully elsewhere in our proceedings, I intend merely to chronicle activities in which I was directly involved, and to try to illustrate the many opportunities for active participation by fellow members.

The Executive held seven meetings in the past year, including one immediately following the annual general meeting in St. John's, two in Ottawa, one in Prince Albert, and two tele-conferences. I also was able to attend meetings of nine Sections or Section Councils, including Newfoundland, Maritime, Champlain, Ottawa Valley, Algonquin, Central Ontario (40th anniversary), Saskatchewan, Rocky Mountain and Vancouver Island. Nine is about $40 \%$ of our Sections; I wish time and our budgets could have enabled more.

I attended several meetings with David Brand and other members of the Algonquin Section. In collaboration with the Petawawa National Forestry Institute, they have undertaken a major initiative to present a national forum on recent advances in forest research in Canada and their possible impacts on forest management practices. The meeting is to be held on October 4, 1988 and the proceedings published in the
The Forestry Chronicle

Volume 64, Numéro 6, décembre 1988 Supplément de l'Assemblée Annuelle

\section{Rapport du Président 1987-88}

J'ai parcouru quelques-uns des rapports des précédents présidents, avant de débuter la rédaction de ce rapport, et j'ai été impressionné par le thème commun soulignant que les progrès de notre Institut dépendent de la contribution sans réserve de plusieurs de nos membres. 1983 n'a pas été une exception, et ma conclusion me permettra d'exprimer mes sincère remerciements.

Puisque les résultats de plusieurs des réunions auxquelles j'ai participé, ont été rapportés en détail dans l'un de nos rapports, j'ai l'intention de référer surtout aux activités auxquelles j'ai été directement impliqué dans le but d'illustrer les nombreuses occasions permettant la participation de tous les membres.

L'Exécutif s'est réuni à sept occasions au cours de l'année, ce qui comprend une réunion immédiatement après l'assemblée générale annuelle de St-Jean, deux réunions à Ottawa, une à Prince Albert, et deux appels conférences. J'ai aussi eu la possibilité d'assister à neuf réunions de sections ou de réunions du conseil de section, dans les Sections TerreNeuve, Maritime, Champlain, Vallée de l'Outaouais, Algonquin, Centre de l'Ontario (40ième anniversaire), Saskatchewan, Rocky Mountain et ile de Vancouver. Ces neuf sections correspondent à $40 \%$ nombre total de sections; j'aurais souhaité avoir plus de temps et les budgets nécessaires pour en avoir visiter plus.

J'ai rencontré à plusieurs reprises David Brand ainsi que les autres membres de la Section Algonquin. En collaboration avec l'Institut forestier national de Petawawa, ils ont entrepris de présenter un forum national sur les récents progrès en recherche forestière au Canada et sur leurs impacts probables sur les techniques d'aménagement forestier. Cette réunion aura lieu le 4 octobre 1988 et le rapport sera publié dans le Journal canadien de recherche forestière. Tous les membres du CIF/IFC recevront ce numéro spécial.

Février a été un mois très occupé! II a débuté par le forum national d'Edmonton sur la recherche: "Innovation et Technologie: la Science dans le Secteur Forestier." Votre Institut était bien représenté à cette conférence "sur invitation" par Claude Godbout, Jim Cayford ainsi que moimême en tant que participants actifs. Un peu plus tard au cours du mois, j'ai participé à la réunion annuelle de "Sylvicon" à Frédéricton. Ceci m'a permis de discuter des activités de notre Institut non seulement avec les membres de la Section Maritime, mais aussi avec les membres de l'"Association of Registered Professional Foresters of New 
Canadian Journal of Forest Research. All CIF/IFC members will be receiving this special issue.

February was a busy month! It kicked off with the National Research Forum in Edmonton: Innovation and Technology Science in the Forestry Sector. Your Institute was well represented at this "by invitation" conference by Claude Godbout, Jim Cayford and myself all being active participants. A little later in the month, I took part in the annual "Sylvicon" meeting in Fredericton. This gave me a chance to discuss activities of our Institute not only with members of the Maritime Section, but also with members of the Association of Registered Professional Foresters of New Brunswick, with the Hon. Morris Green, Minister, NB Department of Natural Resources and Energy, and to make the silver ring presentations to the then soon-to-be graduating class of University of New Brunswick foresters and forest engineers.

On February 23 in Ottawa, we had what has been our semi-annual meeting with the Hon. Gerald Merrithew, former Minister of State for Forestry and Mines. CIF/IFC representatives were $A$. Jones, Chairman Forest Education Working Group, J. Cayford and myself. Minister Merrithew was accompanied by J. Cameron, Policy Advisor and Drs. J.S. Maini and C. Winget. Topics discussed included forest research, federal/provincial forestry agreements, the Minister's participation in this annual general meeting, and some discussion on a forthcoming communicators' forum. The Minister endorsed the idea of regular semi-annual meetings between him and the Institute, and given that our new Minister of State (Forestry), the Hon. G. St. Germain, is joining us at our annual meeting in Prince Albert, I feel this augurs well for the future.

In early March, I attended the Royal Society of Canada workshop on public awareness of science initiatives. I went expecting to find that the various science societies of Canada would be ahead of us in their public awareness efforts. I was therefore pleasantly surprised to find that many of our initiatives, including such items as The Forestry Chronicle, Forestry Dialogue Forestier, our position papers on research, etc., were of great interest to many of the other participants. We still have much to do of course, but we certainly have no need to be apologetic about what we have accomplished to date. The meeting included a reception with the Speaker of the House, the Hon. John Fraser. He discussed the need for a full department of forestry. I also met the Hon. Frank Oberle, and out of these meetings arose a later meeting with the Speaker, a luncheon given by the Speaker during National Foresty Week (May 4) with the CIF/IFC as principal guest, and later that some day, a CIF/IFC President's Reception at the Chateau Laurier for M.P.'s, Senators, and senior executives of industry, and of national and professional associations. The Speaker is a strong ally of forestry; he welcomes our requesting the help of his office to get our message across.

Later in March, I met with President B. Brown of the Ontario Professional Foresters Association and their then newly appointed Executive Director J. Ebbs. Enhanced linkages with the OPFA was our principal topic of discussion. On March 27, your executive met with the Woodlands Section Executive Council of the CPPA. I outlined CIF/IFC organization, objectives and program and we discussed possible areas of collaboration. The Woodlands Section Council outlined their current activities and concerns, including such topics as the use of the lumber export tax for research, and, latterly, I am pleased to acknowledge the direct support of the Woodlands Section Council in their becoming a
Brunswick", avec l'Hon. Morris Green, Ministre des Richesses naturelles et de l'Energie du Nouveau-Brunswick, et de remettre les joncs d'argent aux futurs gradués de foresterie et de génie forestier de l'Université du Nouveau-Brunswick.

Le 23 février, à Ottawa, avait lieu ce qu'il est convenu d'appeller notre réunion semi-annuelle avec I'Hon. Gerald Merrithew, l'ancien Ministre d'Etat aux Forêts et Mines. Les représentants du CIF/IFC étaient $A$. Jones, président du Groupe de travail en Education forestière, J. Cayford ainsi que moi-même. Le Ministre Merrithew était accompagné de J. Cameron, conseiller politique, du Dr J.S. Maini et du Dr C. Winget. Les sujets abordés comprennaient la recherche forestière, les ententes fédérales-provinciales en matière de foresterie, la participation du ministre à l'assemblée générale annuelle et des discussions sur le prochain forum des communicateurs. Le Ministre a approuvé l'idée de réunions semi-annuelles régulières entre lui et l'Institut, et le fait que notre nouveau Ministre d'Etat aux Forêts, I'Hon. G. StGermain, soit parmi nous à cette assemblée générale annuelle de Prince Albert, augure bien pour l'avenir.

Au début de mars, j'ai assisté à l'atelier de la Société royale du Canada sur la sensibilisation du public aux initiatives scientifiques. J'y allais pour voir si les nombreuses sociétés scientifiques du Canada étaient en avance sur nous dans le domaine de la sensibilisation du public. J'ai été toutefois surpris de constater avec satisfaction que plusieurs de nos initiatives, y compris le Forestry Chronicle, le Forestry Dialogue Forestier, nos mémoires sur la recherche, etc., créaient beaucoup d'intérêt chez plusieurs participants. Nous avons évidemment encore beaucoup de chose à faire, mais nous n'avons certainement pas à regretter ce que nous avons fait a date. La réunion comprennait une réception avec le Président de la Chambre, I'Hon. John Fraser. II discuta de la nécessité de créer un vrai ministère des forêts. J'ai aussi rencontré l'Hon. Frank Oberle, et suite à ces rencontres, a suivi une autre réunion avec le Président, un déjeûner offert par le Président lors de la Semaine nationale des Forêts (4 mai) et ayant comme principal invité le CIF/IFC, et plus tard, le même jour, une réception offerte par le Président du CIF/IFC au Château Laurier et destinée aux députés fédéraux, aux sénateurs, aux gestionnaires seniors de l'industrie, et des associations nationales et professionnelles. Le Président est bon allié de la foresterie, il accueille favorablement nos demandes adressées à son bureau pour que notre message soit transmis,

Par la suite en mars, j'ai rencontré le Président B. Brown de l' "Ontario Professional Foresters Association" ainsi que le nouveau Directeur exécutif, J. Ebbs. L'amélioration des relations avec l'OPFA a été le principal sujet de notre conversation. Le 27 mars, votre exécutif a rencontré le Conseil exécutif de la Division des bois et forêts de l'ACPPP. J'ai souligné la structure du CIF/IFC, les objectifs et le programme, et nouv avons discuté des domaines probables de collaboration. Le Conseil de la Division des bois et forêts a abordé leurs activités en cours, leurs sujets d'intérêt, y compris l'utilisation de la taxe d'exportation du bois de sciage pour la recherche, et par la suite j'ai été heureux de souligner l'appui direct du Conseil de la Division des bois et forêts qui est devenu membre corporatif du CIF/IFC. J'ai eu aussi l'occasion de présider l'une des sessions du congrès annuel de l'ACPPP sur l'aménagement forestier.

En avril, tel que mentionné, j'ai rencontré le Président et l'Hon. Frank Oberle, le tout résultant en des réceptions qui ont eu lieu à Ottawa lors de la Semaine nationale des Forêts, au 
sustaining member of the CIF/IFC. I was also able to chair one of the CPPA annual meeting sessions on forest management.

In April, and as mentioned, I met with the Speaker and the Hon. Frank Oberle, one outcome of which were the receptions held in Ottawa during National Forestry Week, the first week of May. I was then out of the country until the end of June, and I wish to express my appreciation to Claude Godbout and other members of the executive for acting on my behalf during that time.

The Banner Issue this past year has been our strategic plan and all issues related to the future development and role of our Institute. Under the able leadership of Vice-president Peter Ackhurst, and his hard working committee of Pat Duffy, Arden Whidden, Harold Pratley, Claude Godbout and Jim Cayford, information has been gathered, positions and options analysed, draft documents prepared, assessed and revised, and working proposals put forward. All of this is reported in more detail elsewhere, and there will be extensive discussions at this meeting. My point at this juncture is to express on behalf of the whole membership our heartfelt thanks for all their efforts so far, and to encourage them as they continue.

One element of the Strategic Plan is the CIF/IFC's role in a national accreditation process for the seven universities offering baccalaureate forestry programs. As many of you may know, a final report has been completed and submitted to the Canadian Federation of Professional Foresters Association (of which the CIF/IFC is a full member) by consultant Dr. V.J. Nordin. Although there are still many details to be ironed out, the Executive of CIF/IFC has proposed that it provide the national headquarters for the yet to be formed "Canadian Forestry Accreditation Board". The Board's secretariat and other office and communication requirements would be provided on some mutually agreed upon fee-for-service basis. I am strongly in favour of this proposal, and there may be further agreements in principle developed at this and possibly subsequent meetings.

Finally, let me thank collectively all those members who have agreed to undertake additional or new CIF/IFC responsibilities. In so doing, I would like to paraphrase Gerry Joudrey, Nova Scotia Section - "... we all achieve from CIF/ IFC what we put into it. Since we are a volunteer organization .. . it is not always possible to give all that we feel we should ..., Like Gerry, I have done what I could, but much remains to be done. I believe the CIF/IFC is making an important contribution to national forestry and that with your continued active participation, our contributions can be enhanced. To borrow from my first alma mater - "Tuum est" - it's up to you. cours de la première semaine de mai. J'ai été à l'extérieur du pays jusqu'à la fin de juin, et j'aimerais remercier Claude Godbout et les autres membres de l'exécutif pour m'avoir remplacer pendant cette période.

Le thème de l'année qui vient de s'écouler à été notre plan stratégique, ainsi que tous les sujets rattachés au développement à venir et le rôle de notre Institut. Sous la gouverne adroite du vice-président Peter Ackhurst, et grâce au travail accompli par le comité formé de Pat Duffy, Arden Whidden, Harold Pratley, Claude Godbout et Jim Cayford, il a été possible de recueillir l'information, d'analyser les positions et les options, de préparer des documents de base, de les évaluer et de les reviser et de déposer un document de travail. Tout ceci est cité ailleurs avec plus de détails, et fera l'objet de plus amples discussions lors de cette assemblée. Je désire exprimer ici au nom de tous les membres, nos plus sincères remerciements pour tous leurs efforts accomplis à ce jour, et pour les encourager à poursuivre.

L'un des éléments du Plan stratégique est le rôle du CIF/ IFC dans le processus d'équivalences nationales pour les sept universités offrant des programmes de baccalauréat en foresterie. Comme plusieurs d'entre vous le savez, un rapport final a été complété et a été soumis à la Fédération canadienne des associations professionnelles de forestiers (dont le CIF/ IFC est un membre actif), un rapport préparé par un consultant, le Dr V.J. Nordin. Même s'il reste plusieurs détails à régler, l'Exécutif du CIF/IFC a proposé que l'Institut devienne le bureau chef pour "le Comité canadien d'équivalences on foresterie" à être mis sur pied. Le secrétariat du Comité ainsi que les autres services de bureau et de communication seraient facturés selon une base de coûts d'utilisation mutuellement acceptée. J'appuie cette proposition, et d'autres accords de principe pourraient être élaborés lors de cette assemblée ou à d'autres occasions.

Finalement, j'aimerais remercier tous les membres qui ont accepté d'entreprendre d'additionnelles ou de nouvelles tâches au sein du CIF/IFC. Pour cela, j'aimerais citer Gerry Joudrey de la Section Nouvelle-Ecosse: “. ... nous retirons du $\mathrm{CIF/IFC} \mathrm{ce} \mathrm{que} \mathrm{nous} \mathrm{y} \mathrm{contribuons.} \mathrm{Puisqu'il} \mathrm{s'agit} \mathrm{d'une}$ organisation basée sur le volontariat ... il n'est pas toujours possible d'y contribuer autant que nous aimerions ...."

Comme le mentionnait Gerry, j'ai fait ce que je pouvais, mais il reste beaucoup à accomplir. Je crois que le CIF/IFC contribue pour une part importante à la foresterie au Canada et grâce à notre participation soutenue, notre contribution peut être plus efficace. Je citerais ma première devise: "Tuum est" C'est à vous d'y voir.

\section{A.J. Kayl}

\section{The Executive Director's Report, 1987-88}

It is a pleasure to once again be closely involved with the Canadian Institute of Forestry/Institut Forestier du Canada after having served on the Executive Committee during the period 1980-84. During 1987-88 the responsibilities of the Executive Director have been filled by Doug Redmond, Bob Bourchier and myself. I would like to acknowledge the contributions of both Doug and Bob; as a result of their efforts I was able to step into a smoothly running office.

My report will be in three sections - administration, project officer and communications and liaison.

\section{Administration}

In 1987-88 revenues and expenditures were in balance, but our overall financial situation is tight. We have an accumulated deficit which resulted from the move to Ottawa in the early 1980s. This deficit maximized in 1983-84 at \$33134. Although reduced by $\$ 620$ in 1987-88 it remains at $\$ 19195$. Our financial situation seriously constrains any efforts to increase our programming and requires that dues be increased annually at a level that at least matches increases in the cost of living. 
Forestry Chronicle operations are outlined by the Editor and the Production Manager. The net cost of the journal in $1987-88$ was approximately $\$ 15000$ up from $\$ 9700$ in 198687 but less than the $\$ 21600$ in 1985-86. Expenditures increased to $\$ 86000$, an increase of $\$ 9000$ from 1986-87; revenues increased by $\$ 3000$ as a result of increases in the sale of reprints and subscriptions. Special features published in The Forestry Chronicle included the Annual Meeting Report, October, the National Forest Sector Strategy for Canada, October, By-Laws, Rules and Regulations, December, and proceedings of a Forestry Wildlife Symposium, June. An advertising campaign will be initiated early in 1988-89.

The Foresters' ring program continued in 1987-88 and a member of the Executive Committee or the Executive Director was present at all ceremonies. In total we presented 304 rings during 1987-88. During the year the International Forestry Award was initiated and will be awarded at Prince Albert. Other award winners are noted elsewhere.

The 1988 Annual Meeting is being hosted by the Saskatchewan Section in Prince Albert, September 18-22, 1988. The initial HAMPCO chairman was Chris Lee, but following his move to Ottawa, Jamie Benson has had the responsibility. The Executive Committee met in Prince Albert in November 1987 and the Executive Director met with the Section and with HAMPCO in April 1988. The 1989 Annual Meeting will be in Kananaskis County, Alberta, and the Executive Director is in close contact with Chuck Geale, 1989 HAMPCO Chairman.

Since the 1987 Annual Meeting the Executive Committee has met seven times. There were four meetings and three teleconferences. Meetings were held on September 15, 1987 in Ottawa, on November 16 and 17 in Prince Albert, on March 27 in Montreal and on May 4 in Ottawa. Teleconferences were held on January 15, March 1 and August 2. The Executive Director is aresponsible for agenda preparation, recording of minutes and o follow-up action as required.

During the year we have renamed our newsletter. It is now Forestry Update/Information Forestiere rather than the familiar PRESTOSEC. The change was considered necessary because we now distribute the newsletter beyond the CIF/IFC, to all members of the Forestry Constituency. Following his return to work last fall, Bob Bourchier produced two issues, Vol. 11, No 2 and 3. Since January the newsletter has been issued monthly on the first of each month.

Membership records, Forestry Chronicle subscriptions and other selected lists are maintained on our computer. A variety of labels and membership lists can also be produced. Dues notices were issued in early May; follow-up reminders will be issued in September and December. Other administrative duties of the Executive Director involve correspondence, including that relating to resolutions, serving as business manager of The Forestry Chronicle, providing support, information and documentation to Institute boards, committees, sections and working groups, and managing the annual election.

\section{Project Officer}

During the past year the Institute has embarked on three major new initiatives, all of which have required input from the Executive Director.

The first initiative involves the preparation of a Strategic Plan. This activity has been under the direction of 2 nd Vice-
President, Peter Ackhurst. I have been involved as a member of the Strategic Planning Task Force, have provided secretarial support to the Task Force, summarized responses to the initial discussion paper and have participated in the writing and editing of the draft plan.

The second initiative is the organization, collaboratively with the Canadian Forestry Service, of a symposium entitled Advances in Canadian Forest Research. The symposium is being held at the Petawawa National Forestry Institute, October $3-4,1988$ and the lead role is being taken by the Algonquin Section. I have provided liaison between the Organizing Committee and the Executive Committee and participated in one meeting of the Organizing Committee.

The third initiative is the organization of the Forestry Communicators Workshop. This workshop is being organized in conjunction with the Canadian Forestry Service, Canadian Forestry Association, Canadian Pulp and Paper Association, Canadian Council of Forest Ministers and the Council of Forest Industries of B.C. Dave Fayle is the chairman of the Steering Committee for the workshop, while I serve as its secretary. The workshop is scheduled for March 1989 in Toronto.

Other specific projects in which I have been involved include Forestry Dialogue Forestier, the Institute's information sheet for federal parliamentarians. Over the past year distribution has been extended to include the Forestry Constituency, Canadian Forestry University Heads, trade journals, members of the Ottawa Press Gallery and members of the Canadian Council of Forest Ministers. Five issues have been prepared and distributed since the beginning of the year:

12. A National Forest Sector Strategy (January)

13. Federal Provincial Forestry Agreements (March)

14. Canada Needs a Federal Department of Forestry (April)

15. Forest Research Needs Strengthening (May)

16. Sustainable Development (July)

17. Forestry and Wildlife (August)

Several other issues are in various stages of preparation.

Other activities have involved serving as a representative of the eastern members of the Canadian Federation of Professional Foresters Associations, including the CIF/IFC, on the Steering Committee for the National Accreditation Study undertaken by Dr. V.J. Nordin and writing a number of articles for The Forestry Chronicle.

\section{Communications and Liaison}

An important role carried out by the Executive Director involves communication and liaison both within the $\mathrm{CIF} / \mathrm{IFC}$ and with a wide variety of the agencies.

I have viewed my first responsibility as one of internal communications, within the organization. Regular contact is maintained with members of the Executive Committee and with the majority of sections. I have also been fortunate to have had the opportunity to meet with 12 of our 23 sections; Nova Scotia, PEI sub-section of Maritimes, Champlain, Ottawa Valley, Algonquin, Southern Ontario, Central Ontario, Northwestern Ontario, Saskatchewan, Rocky Mountain, Okanagan and Vancouver. These visits provide an excellent opportunity for two-way dialogue.

During the year the Institute has maintained continuing contact with the Hon. G.S. Merrithew, Minister of State (Forestry 
and Mines). The Executive Committee met with him in St. John's Nfld. in August and again in February in Ottawa. I have also met officials of Mr. Merrithew's staff and senior officials of the Canadian Forestry Service, the Canadian International Development Agency and Fisheries and Oceans Canada. Contact has also been maintained with the House of Commons Standing Committee on Environment and Forestry and a brief was prepared on Forestry and Wildlife for a special session of the Committee. The CIF/IFC has also been requested to appear before the Committee to discuss the use of pesticides in forestry.

I continue to serve as a member of the Executive Board of the International Union of Forestry Research Organization (IUFRO) and as Chairman of its Administration Committee. I attended the Board meeting in Rome in December 1987. I am also a member of the Steering and Excursion Committees for the 1990 IUFRO World Congress to be held in Montreal, August 1990.

Contact has also been maintained over the past months with the provincial Registered Professional Associations, Canadian Forestry Association, Woodlands Section of the Canadian Pulp and Paper Association, Canadian Wood Council, Canadian Wildlife Federation, the Society of American Foresters and the International Union of Societies of Foresters.

In closing I wish to thank Denise Trepanier, our Office Manager, for her service and support, the Executive Committee, and all members who have contributed towards the objectives of the Institute.

J.H. Cayford

August 9, 1988

\section{Editor's Report}

The Forestry Chronicle is primarily a professional periodical whose contents should reflect the interests and needs of the CIF members. Its editorial policy is as follows.

The Chronicle will publish scientific and technical articles, which will receive peer reviews from at least two outside reviewers. These papers, however, should be aimed at the practicing forester or resource manager, not at the professional researcher. It will also publish professional papers and the proceedings of symposia or workshops relating to forestry. Professional papers may cover case histories in forest management, current forestry issues, forest history and so on. They may be more speculative and argumentative than scientific papers, but will not usually include research results and will usually be reviewed only by me and one of the associate editors. In addition, the Chronicle usually makes a practice of publishing certain important policy documents dealing with forestry. The October ' 87 issue, for example, includes the text of "A National Forest Sector Strategy for Canada - July 1987" in both French and English.

Table 1 gives the comparative data in the contents of The Forestry Chronicle for 1986, 1987 and the first three issues of 1988. The number of papers being submitted has increased from about 45 in 1983 to 70 in 1986 and ' 87 , and will probably run to 85 this year. Volume 63 (1987) was somewhat shorter than usual because it contained relatively few pages of symposia proceedings, but Volume 64 (1988) will number close to 600 pages. Volume 65 may be somewhat longer again because it will probably include the proceeding of a lengthy symposium on site quality. Incidentally, a regular issue
Table 1. Comparative Data on The Forestry Chronicle for 1986, 1987 and 1988

\begin{tabular}{lclc}
\hline & $\mathbf{1 9 8 6}$ & $\mathbf{1 9 8 7}$ & $\mathbf{1 9 8 8}^{\mathbf{1}}$ \\
\hline Total pages & 588 & 504 & 295 \\
Page of technical articles & $170(34)^{2}$ & $133(26)^{2}$ & $78(14)^{2}$ \\
Pages of professional articles & $76(16)^{2}$ & $100(26)^{2}$ & $34(8)^{2}$ \\
Pages of symposia or work- & & & \\
$\quad$ shop proceedings & $114(16)^{2}$ & $46(5))^{2}$ & $8(20)^{2}$ \\
Pages of other material & 228 & 225 & 97 \\
No. of articles submitted & 70 & 70 & 52 \\
No. of articles under review & 50 & 55 & 59 \\
No. of articles rejected & 14 & 15 & 7 \\
\hline
\end{tabular}

'Data for first three issues only.

${ }^{2}$ No. of articles published.

usually takes me 80 to 100 hours to prepare; those including proceedings take considerably longer. There is no doubt that I could improve the Chronicle by spending more time on it, but my wife insists that I am retired.

In conclusion, I again wish to thank the associate editors and reviewers for their unselfish efforts on behalf of The Forestry Chronicle. In particular, I wish to thank Dr. J.T. Basham for his work in forest pathology papers; Jack relinquished, his associate editorship this year because of retirement from the CFS. And as usual, I must mention Dr. V.G. Smith (mensuration and biometrics) who carried more than a fair load of editing despite being on sabbatical leave.

I.C.M. Place August 9, 1988

\section{Production Manager's Report}

This report covers production of The Forestry Chronicle for the Fiscal Year 1987-1988 and, therefore, deals with the publication of the last three issues of Volume 63 and the first three of Volume 64.

Table 1 compares the contents of our publication for the last three Fiscal Years: $1985 / 86,1986 / 87$ and $1987 / 88$. The greatest difference is the increased number of professional articles in $1987 / 88$. Note that a symposium has been included during each period.

Producing and mailing a publication of this nature on schedule requires vigorous observance of the cut-off date for

\begin{tabular}{|c|c|c|c|}
\hline & $1985 / 86$ & $1986 / 87$ & $1987 / 88$ \\
\hline $\begin{array}{l}\text { No. of scientific and technical } \\
\text { articles }\end{array}$ & 27 & 35 & 32 \\
\hline $\begin{array}{l}\text { Pages of scientific and technical } \\
\text { articles }\end{array}$ & 134 & 186 & 171 \\
\hline No. of professional articles & 18 & 17 & 24 \\
\hline Pages of professional articles & 89 & 75 & 96 \\
\hline Pages devoted to symposia & 48 & 114 & 64 \\
\hline Pages of other material & 235 & 223 & 245 \\
\hline Total pages & 506 & 598 & 576 \\
\hline
\end{tabular}


Salaries were down because of the transition between Bob Bourchier and Jim Cayford. Postage and telephone costs were also down due to a slowing of office activity during this period. Executive Director travel was also down for this reason. Chronicle costs were up because of special items such as the CIF/IFC bylaws and the National Forest Strategy. One-time expenses such as Jim Cayford's moving expenses, the Strategic Planning Task Force and the National Accreditation Project make up the bulk of Sundry Expenses.

Our surplus of $\$ 2304.00$ is a good sign, keeping in mind that our deficit stands at $\$ 19195$ compared with the all-time high of $\$ 33134$ in 1983-84.

\section{Proposed Budget for 1988-89 (Table 1)}

A steady increase in membership is expected, consequently a corresponding increase in revenue. Increased Chronicle advertising will be a prime objective.
Expenditures include permanent salaries rising to their normal level with a slight increase and a decline in casual salaries. Communication costs in the form of postage and telephone will be up. The new FAX machine should result in more efficiency and possibly reduce costs. Travel by the Executive Director will be up as he familiarizes himself with the Sections. Director travel is trending upward as some employers are withdrawing travel support. An increase in translation costs is expected. The Chronicle costs will be held close to the 1988 level if possible.

We are aiming for a balanced budget in 1988-89. staff.

Many thanks to Jim Marshall and Jim Cayford and his

Mark Schaefer, R.P.F. Chairman

\section{Auditors' Report}

We have examined the balance sheet of the Canadian Institute of Forestry - Institut Forestier du Canada as at June 30,1988 , and the statement of operations and deficit for the year then ended. Our examination was made in accordance with generally accepted auditing standards, and accordingly included such tests and other procedures as we considered necessary in the circumstances.

In our opinion, these financial statements present fairly the financial position of the Institute as at June 30,1988, and the results of its operations for the year then ended in accordance with generally accepted accounting principles applied on a basis consistent with that of the preceding year.

OTTAWA, August 3, 1988

Cook, Perry, Sewell \& Co. Chartered Accountants

Balance Sheet - June 30, 1988

\begin{tabular}{|c|c|c|}
\hline ASSETS & 1988 & 1987 \\
\hline \multicolumn{3}{|l|}{ Current Assets } \\
\hline Cash and term deposits & $\$ 65681$ & $\$ 92652$ \\
\hline Accrued interest receivable & 348 & 264 \\
\hline Accounts receivable & 19150 & 11699 \\
\hline & 85179 & 104615 \\
\hline
\end{tabular}

Fixed Assets

Office furniture and equipment

$\underline{\underline{\$ 85180} \quad \underline{\$ 104616}}$

\section{LIABILITIES AND CAPITAL DEFICIENCY}

\section{Current Liabilities}

Accounts payable and accrued liabilities

Dues and subscriptions received in advance

$$
\begin{array}{rr}
\$ 21982 & \$ 13806 \\
\frac{82393}{104375} & \frac{110625}{124431}
\end{array}
$$

Deficit

$\underline{\underline{(19195)} \quad \underline{(19815)}} \underline{\underline{\underline{\$ 104616}}}$

\begin{tabular}{|c|c|c|}
\hline & 1988 & 1987 \\
\hline \multicolumn{3}{|l|}{ Revenues } \\
\hline Advertising & $\$ 13732$ & $\$ 16290$ \\
\hline Page charges & 17698 & 17927 \\
\hline Reprints & 11435 & 8920 \\
\hline \multirow[t]{2}{*}{ Subscriptions and sales } & 28562 & 24964 \\
\hline & $\overline{\$ 71427}$ & $\$ 68101$ \\
\hline \multicolumn{3}{|l|}{ Expenditures } \\
\hline Editor's honorarium & $\$ 4385$ & $\$ 3480$ \\
\hline Mailing & 8057 & 7060 \\
\hline Printing & 60420 & 56962 \\
\hline Production & 5883 & 5705 \\
\hline Reprints & 4485 & 3570 \\
\hline Miscellaneous & 3375 & 1043 \\
\hline & $\overline{\$ 86605}$ & $\$ 77820$ \\
\hline \multicolumn{3}{|l|}{ Net cost of operating the } \\
\hline Forestry Chronicle & $\$ 15178$ & $\$ 9719$ \\
\hline
\end{tabular}

\section{Revenues and Expenditures for the Year Ended June 30, 1988}

Notes to the Financial Statements, June 30, 1988

\section{Significant accounting policy Fixed assets}

Purchases of office furniture and equipment are charged directly to expenditures. A nominal value of $\$ 1$ is carried on the balance sheet in recognition of the existence of such assets.

\section{Other financial information}

The Institute, incorporated Federally as a corporation without share capital, qualifies as a non-profit organization for an exemption from income tax under Federal and Ontario legislation. 


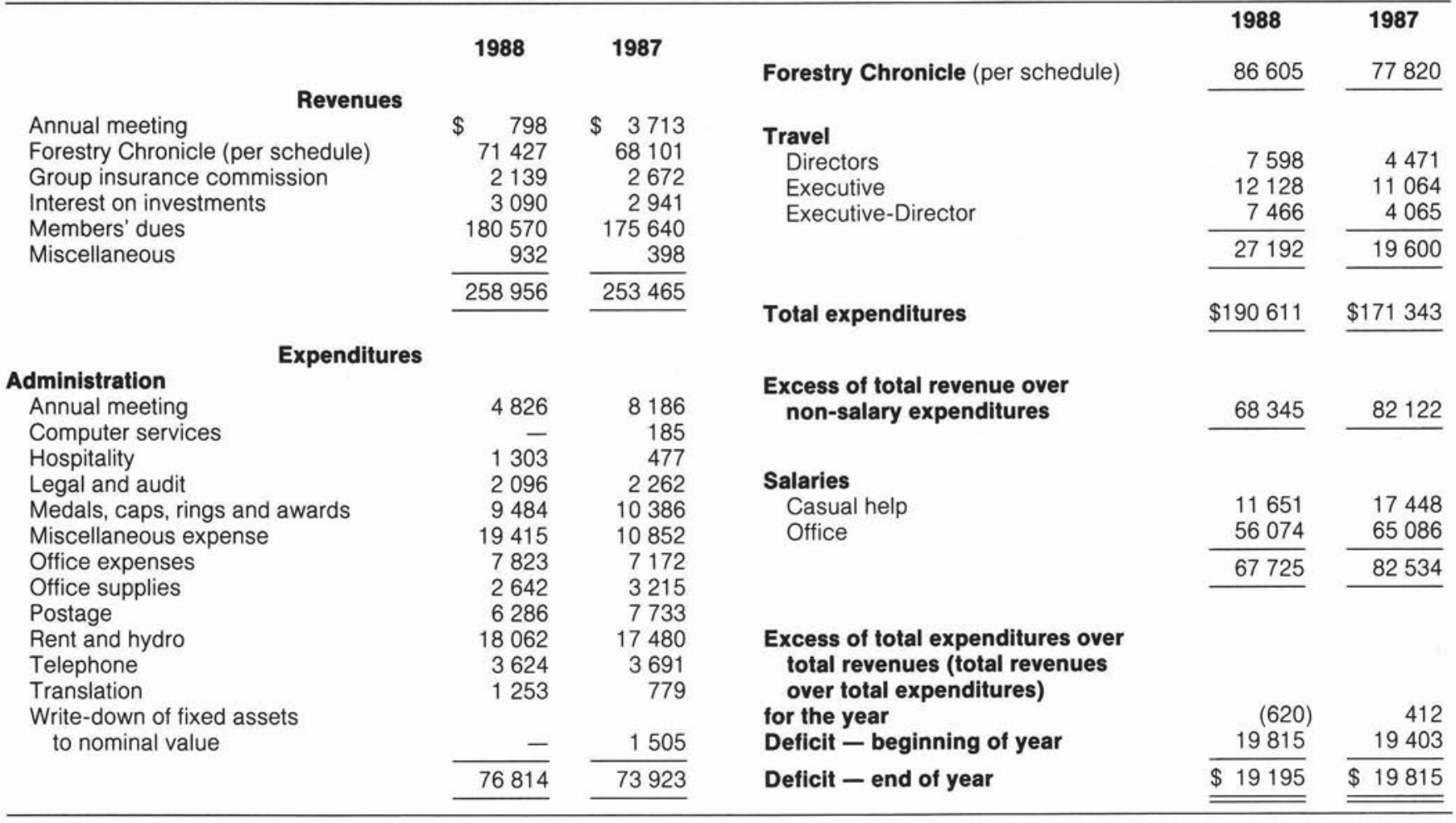

\section{Forestry Awareness in Canada Trust Committee (FACT)}

\section{7-1988 Annual Report}

\section{Introduction}

The 1987-88 year was an active one for the committee.

We received six project proposals for FACT seed money. We began the process of preparing a catalogue of Forestry Educational Tools and Materials for secondary and elementary schools. Throughout our deliberations, we did not lose sight of our original goal of concentrating our efforts on the future generations and the necessity of making them forestry aware.

We thank Bob Bouchier for his hard work and efforts as Trustee and Secretary and wish him all the best. Jim Cayford has taken on Bob's responsibilities on the committee. We look forward to a long association with Jim.

The 1987-88 FACT Board of Trustees is:

Glen Swant, President

Ernie Heidersdorf, Trustee

Jim Kayll, Trustee

Jim Cayford, Trustee and Secretary

\section{Activities}

Applications for Project Assistance

We received six proposals. Two proposals were not granted funding; one proposal is awaiting further information; and three projects were approved for funding.

FACT is a source of seed money for awareness projects; it is not a subsidy nor is it the prime source of funding. A project must have a country-wide application. Regional applications are received but they are approved for funding only if they can be applied across Canada. These two criteria are most commonly used when considering projects for approval.

The following is a brief description of the projects that were approved for funding:

Project \#1

Title: $\quad$ Provision of Forestry Computer Games to school boards within Central Ontario Section

Section: Central Ontario Section, Sault Ste. Marie,

Project

Leader: B.W. Smith

Description of Section purchased copies of three computer Project: $\quad$ games produced by CFS and then distributed them to school boards in the Section.

The games are Dispatcher, Forest Management, and Integrated Forest Management.

FACT Funding

Received: $\$ 1000$

Project \#2

Title: Mountain Pine Beetle Model

Section: $\quad$ Skeena Section, Smithers, B.C.

Project

Leader: R. Alan Gorley

Description of Provide for a prize, Forestry Awareness Project: presentations and information for a school and club contest in the Skeena area to build the best Mountain Beetle Model.

FACT Funding

Received: $\$ 250.00$ 
Project \#3

Title:

Section:

Project

Leader:

Hersey Lake Demonstration Forest

Northern Ontario Section, Timmins, Ontario

Description of Establish an outdoor education program and Project: support facility geared to teaching the principles of forest management. The application concentrates on the first phase of the education component whereby two teachers will be hired to develop an education

FACT Funding program for grades 4 to 6 .

Received: $\$ 750$

Project \#4

Title:

A book entitled "The Tale of the Forest of Havella Land"

Introduction: A formal application has not been submitted. But a copy of the transcripts have been reviewed by the President of FACT. Board and preliminary approval was given to develop the project for FACT assistance.

Project

Leader: Jon Williams, PNFI, Chalk River, Ontario, Algonquin Section

Description of The book is designed for Canadian grade Project: school children as an educational story book on forest management. The book, in its final form, will be a children's story book; much like the story book "Swiss Family Robinson" for example, except that it will have a number of challenge components where the reader makes a choice and the decision leads the story in a certain direction. Thios approach is intended to show the complexity of forest management.

Intent of FACT:When the book is fully developed, we shall contribute and solicit funds towards publishing the book.

Jon Williams of PNFI supplied the committee with a copy of the joint OMNR/CFS Forestry Education ProjectElementary Outline which is funded through the Canada/ Ontario Forest Resource Development Agreement.

This is a very thorough and well prepared program for school children. future.

It is a project that FACT may want to contribute to in the

\section{Summary}

It is very encouraging to see the Sections getting involved. Initially the committee was working on their projects, now we can work on everybody's project from all corners of the country. But the most exciting part is that a number of sections feel that educating the next generation is necessary to improving the forestry awareness of the nation.

We look forward to even more active program in 1988-89.

G.R. Swant

President, FACT Committee

\section{Auditors' Report}

\section{To the Trustees of the}

\section{Forestry Awareness In Canada Trust}

We have examined the balance sheet of the Forestry Awareness In Canada Trust as at June 30,1988 and the statement of operations and surplus for the year then ended. Our examination was made in accordance with generally accepted auditing standards and accordingly included such tests and other procedures as we considered necessary in the circumstances.

As is usually the case in organizations receiving donations, the verification of such items was impracticable beyond accounting for amounts recorded in the books of the organization

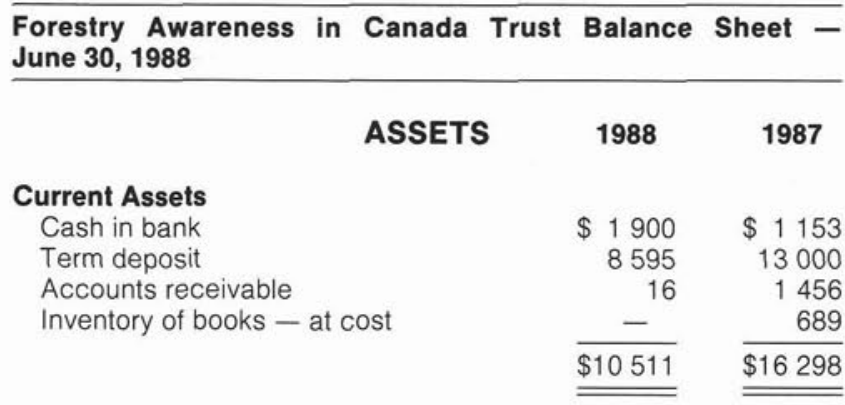

EQUITY

\section{Surplus}

$\$ 10511 \quad \$ 16298$
In our opinion, except for the effect of adjustments, if any, which might have resulted had we been able to verify donations, these financial statements present fairly the financial position of the trust as at June 30,1988 and the results of its operations for the year then ended, in accordance with generally accepted accounting principles applied on a basis consistent with that of the preceding year.

OTTAWA, August 3,1988

Cook, Perry, Sewell \& Co. Chartered Accountants

Forestry Awareness in Canada Trust Statement of Operations and Surplus for the year ended June 30, 1988

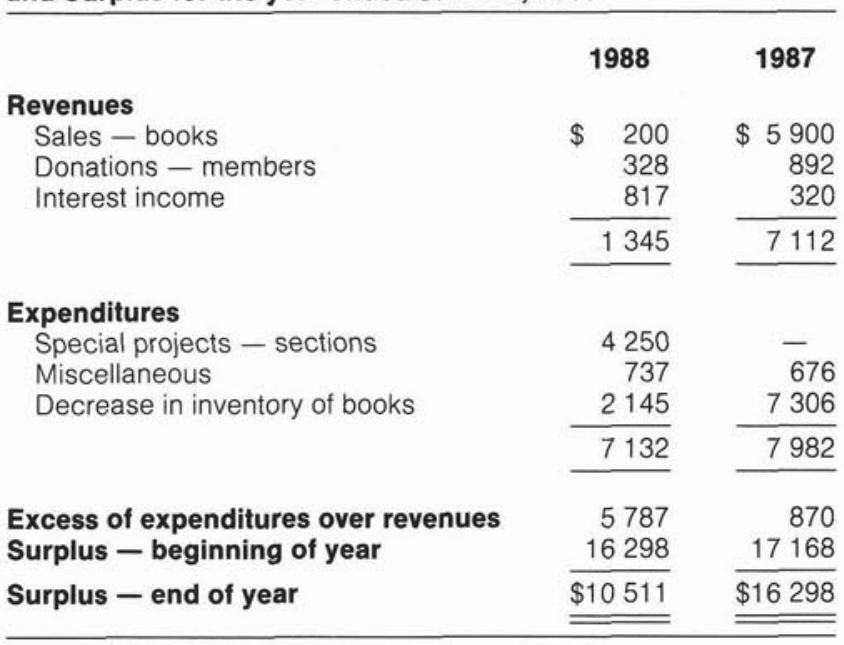




\section{Membership Committee Report, 1987/88}

Membership in the CIF/IFC over the past five years was reviewed in conjunction with the development of a Strategic Plan. Membership immediately after the removal of members for non-payment of dues (March 1988) was 2350 which represented an increase of 234 from 1987 but was similar to the 1986 figure of 2310 . During the past five years membership has been relatively static (Table 1 ). However, in view of the fact that there have been 300 to 400 graduates each year, our percentage of potential members is declining. Potential membership is at least 6000 .

The recruiting prize for $1987-88$ was won by the Orleans Section (Table 2). Other sections deserving honorable mention are Northwestern Ontario, Nova Scotia, Maritime and Newfoundland. By late August membership had shown a small increase (2.3\%) since March.

J.H. Cayford, R.P.F. August 31, 1988

Table 1. CIF/IFC Membership, 1984 to 1988.

\begin{tabular}{lrrrrr}
\hline Membership & $\mathbf{1 9 8 4}$ & $\mathbf{1 9 8 5}$ & $\mathbf{1 9 8 6}$ & $\mathbf{1 9 8 7}$ & $\mathbf{1 9 8 8}$ \\
\hline Active & - & 1842 & 1815 & 1578 & 1646 \\
Affiliate & - & 87 & 75 & 54 & 66 \\
Fellow & - & 31 & 31 & 29 & 31 \\
Honorary & - & 4 & 6 & 6 & 6 \\
Retired paying & - & 112 & 119 & 136 & 147 \\
Retired non-paying & - & 116 & 116 & 110 & 116 \\
Students & - & 171 & 148 & 74 & 195 \\
Non-members & 2435 & 2363 & 2310 & 2116 & 2350 \\
\hline Total & & - & - & 129 & 143 \\
\hline
\end{tabular}

Number of members following removal of members for non-payment of dues (January 1984, 1985, 1986, March 1987, 1988). Non-members are members of the Alberta Registered Professional Foresters Association but have not completed an application.

Table 2. Number of New Members by Section, September 1, 1988.

\begin{tabular}{|c|c|c|c|}
\hline Section code & $\begin{array}{c}\text { Number of } \\
\text { new members }\end{array}$ & $\begin{array}{c}\text { Number of } \\
\text { members }\end{array}$ & Percentage \\
\hline Algonquin & 0 & 50 & 0.00 \\
\hline Cariboo Chilcotin & 0 & 23 & 0.00 \\
\hline Cariboo & 6 & 85 & 7.06 \\
\hline Central Ontario & 9 & 108 & 8.33 \\
\hline Champlain & 5 & 54 & 9.26 \\
\hline Kootenay & 0 & 13 & 0.00 \\
\hline Lake of the Woods & 0 & 42 & 0.00 \\
\hline Manitoba & 3 & 48 & 6.25 \\
\hline Maritime & 22 & 177 & 12.43 \\
\hline Newfoundland & 7 & 65 & 10.77 \\
\hline Northern Ontario & 1 & 20 & 5.00 \\
\hline Northwestern Ontario & 18 & 108 & 16.67 \\
\hline Nova Scotia & 15 & 114 & 13.16 \\
\hline Okanagan & 2 & 37 & 5.41 \\
\hline Orleans & 16 & 90 & 17.78 \\
\hline Ottawa Valley & 5 & 114 & 4.39 \\
\hline Pacific & 3 & 47 & 6.38 \\
\hline Rocky Mountain & 32 & 415 & 7.71 \\
\hline Saskatchewan & 4 & 50 & 8.00 \\
\hline Skeena & 2 & 24 & 8.33 \\
\hline Southern Ontario & 11 & 187 & 5.88 \\
\hline Vancouver & 23 & 308 & 7.47 \\
\hline Vancouver Island & 9 & 166 & 5.42 \\
\hline Unclassified & 1 & 49 & 2.04 \\
\hline Total & 194 & 2394 & 8.10 \\
\hline
\end{tabular}

\section{Board of Examiners Annual Report $-1987 / 88$}

The Board of Examiners, consisting of A Dickson (Maritime), D. Golding (Vancouver) and the undersigned, received only one application for active membership, that of Mr. Raymond Hatch, with support from the
Vancouver Section Council.

After reviewing the application, the Board agreed that Mr. Hatch should be granted active membership in the CIF/IFC.

J.R. Carrow Chairman June 30,1988

\section{Report of the By-Laws Committee,} 1988

No actions were undertaken by the Committee, and no changes in by-laws were proposed to the Committee, during the year.

Membership: P.E. Zundel,

\section{A.L. VanSlyke (Chairman)}

August 1988

\section{Nominating Committee Annual \\ Report - 1987-88}

The call for nominations for the positions of First and Second Vice-President on the CIF/IFC National Executive was sent to Section Chairmen and Directors on December 2, 1987. At the same time, President Kayll appointed a Nominating Committee with the following membership:

J. Torunski, Maritimes

R. Bronstein, Vancouver

D. Rannard, Manitoba

R. Carrow, Past-President (Chairman)

Nominations were to be forwarded to the Nominating Committee by March 31 , 1988. No nominations for the position of First Vice-President were received. For the position of Second Vice-President, three candidates were nominated.

These nominations were reviewed by the Committee to ensure that they were procedurally correct and the documentation was complete. The three candidates for Second Vice-President were:

1. Douglas P. Drysdale, Southern Ontario

2. C.H. (Harry) Gairns, Cariboo

3. Jack C. Wright, Rocky Mountain

These nominations and the supporting documentation were forwarded to the Executive Director on May 10, 1988.

I would like to thank members of the Nominating Committee and Section Chairmen for their assistance in developing a very capable slate of candidates for National Executive.

\section{J.R. Carrow Chairman June 30,1988}

\section{Report of the Awards Committee - 1987/88}

Chairman:

Members:

Secretary:

\section{A.J. Kayll Executive Committee J.H. Cayford}

The Awards Committee is the Executive Committee sitting as a special committee of the whole. During 1987-88 a new award will be initiated; The International Forestry Achievement Award. Recipients for the Canadian Forestry Achievement Award, the Canadian Forestry Scientific Achievement Award and the International Forestry Achievement Award were selected at the August 2 meeting of the Awards Committee. The awards will be presented at the 1988 Annual Meeting. One individual was nominated for Fellow Membership status 
and a decision will be made at the Directors' meeting in Prince Albert. Two special awards are currently being considered by the Awards Committee. Other awards include six Gold Medals, the Schlich Award, Golden Year Members and Foresters Rings. These awards are managed by the Executive Director and will be announced at the Annual Meeting.

J.H. Cayford August 10, 1988

\section{Report of the Resolutions Committee - 1987/88}

The call for resolutions for the 1987 Annual General Meeting of the CIF/IFC was sent out to Section chairpersons by the Executive Director on 2 March, 1987. As in previous years, only a very few of the total number of resolutions eventually presented to the membership at the AGM were received as a result of this process Most were received at the AGM itself and several of those received prior to the AGM were either withdrawn or heavily revised by the proponents before reaching the floor of the meeting.

Of the 20 resolutions presented to the membership by the Chairman, 10 were "external" resolutions (directing action to be addressed to target audiences external to the CIF/IFC), seven were "internal" resolutions (directing action to be taken within the $\mathrm{CIF} / \mathrm{IFC}$ ), one was an hybrid external/internal and two were "standard" resolutions specifically, ratification of the actions of the Executive Committee and the Board of Directors and appreciation to the Newfoundland Section for its hosting of the AGM. All 20 resolutions were carried.

My thanks to Les Carlson and Francois Sauvageau for their many hours of assistance during the course of the meeting which allowed the presentation of the resolutions in an expeditious and coordinated manner. Much discussion took place with the proponents during the course of the meeting to ensure proper wording and to avoid overlap between resolutions. The breadth of topics, the quality of the resolutions, and the interest of the membership shown in the discussions of the resolutions attest to the importance of this mechanism in the development of the annual activity program of the Institute.

In referring back to my opening paragraph, I strongly recommend that the Board of Directors give consideration to the current direction for the submission of resolutions. The rules for the presentation of resolutions at an AGM state that, except for standard resolutions and those arising from the business of the AGM, resolutions "shall be submitted to Head Office at least five weeks prior to the Annual General Meeting". From the experience of the $1987 / 88$ AGM, and from the reports of previous Resolutions Committee Chairmen, this procedure is, clearly, not working. Most resolutions presented are all but spontaneous in that they are submitted to the Resolutions Committee up to only a few hours prior to their presentation. At the 1987 AGM the Committee was directed by the CIF Executive to receive such submissions. This degree of flexibility makes it difficult for the Resolutions Committee to perform its tasks effectively and can lead to wasted time at the business session at which the resolutions are presented.

\section{L.F. Riley}

Chairman

\section{Publication Policy Committee Report - 1987/88}

\section{Terms of reference}

1. To maintain a continuing review of existing CIF/IFC publications and publication policies

2. To provide advice and guidance to the Editor of The Forestry Chronicle.

3. To carry out special assignments dealing with the CIF/IFC publications and publication policies as requested by the Executive Committee.

\section{Membership}

J.H. Smyth, D. Lockhart, P.E. Vezina, and J.H.G. Smith (Chairman).

\section{Accomplishments}

Members of the Committee continued to monitor The Forestry Chronicle and appear to be satisfied with its contents and presentation. Suggestions for improvement are always welcome.

Only one item was referred to us by the Executive Committee. That was the resolution that the CIF/IFC consider the feasibility of publishing The Forestry Chronicle in English and French, "to ensure better representation and communication toward all Canadians, to expand the distribution network of The Forestry
Chronicle and to include more publicity related to private sector expertise". Learning that the extra costs involved would amount to $\$ 60$ or more per member. we considered that in practical terms the costs are prohibitive and the benefits marginal. We expected that CIF/IFC would lose more members as a consequence of increased dues than might be gained by having a bilingual publication. We did, however, want to commend those that put the resolution forward and to draw attention to the need for individuals to submit more professional articles, with emphasis on private sector expertise.

Relationships of this Committee to Prestosec (now Forestry Update/Information Forestier) to Forestry Dialogue Forestier and to policy statements is not clear.

We noted with interest that Dr. B.P. Dancik, Editor Canadian Journal of Forest Research, is Chairman of the NSERC Grant Selection Committee on Scientific Publications and a member of the National Research Council of Canada's National Advisory Board on Scientific Publications. Early efforts of the CIF/IFC to stimulate publication of a scientific journal for forestry have paid off very well and now allow The Forestry Chronicle to emphasize professional and technical information, leaving scientific articles to the Canadian Journal of Forest Research.

\section{J. Harry G. Smith} Chairman

\section{Archival Committee Report - 1987-1988}

The Archival Committee was established in 1987 at the Annual Meeting in St. John's. The motion of establishment and

\section{Board of Directors at the CIF Annual Meeting in Prince Albert, September, 1988}

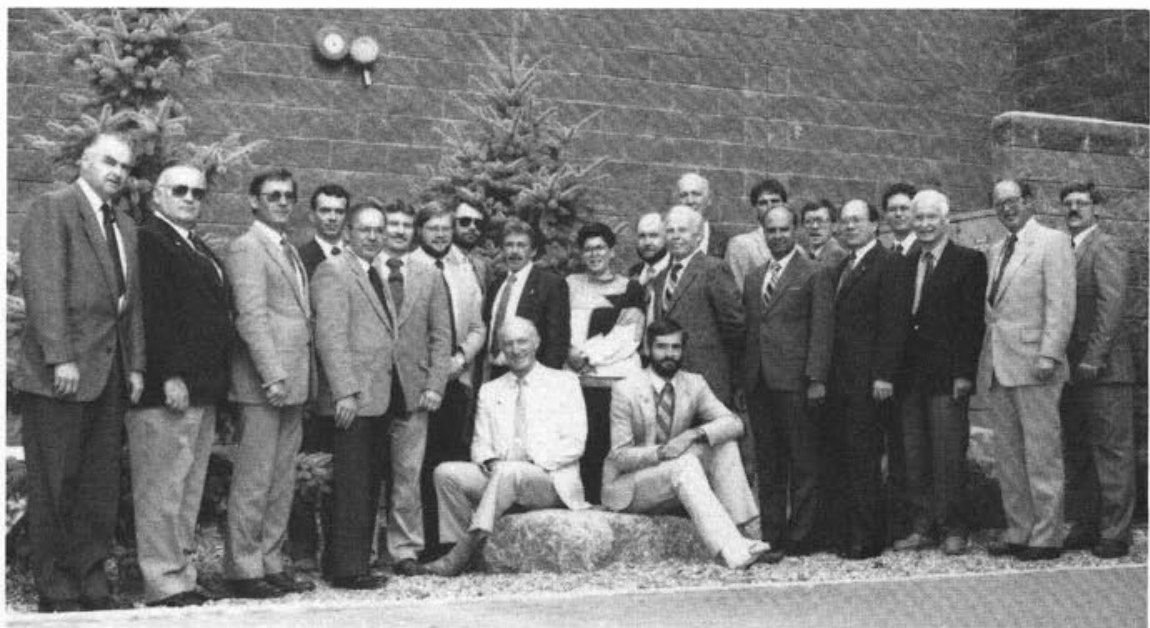

Board of Directors at the CIF Annual Meeting in Prince Albert, September, 1988.

(Back: left to right) Jim Cayford, Barry Smith, Murray Little, Don Couch, René Doucet, John Elmslie, Mike Power, Steve Talbot, Johanne Gauthier, Jack Heidt, Mack Williams, Jim Kayll, Rick Slaco, Charles John, Peter Ackhurst, Claude Godbout, Brian Murphy, Peter Paul, Richard Campbell, Gardy Ardron

(Front: left to right) Rod Carrow, Ron Smith. 
the CIF Executive defined the following terms of reference in part.

1. Establish a National Committee with the objective of acquiring and preserving archival material germane to forestry in Canada and to the CIF/IFC

2. Notify CIF Sections of the existence of the Committee and request names of contacts who would respond to suggestions of the National Committee.

The National Committee was established early in 1988, composed of the following well known CIF members: W. Young, B.C.; C.K. Smith, Prairies; D.P. Drysdale, Ont.; F. Matte, Que.; R. Spurway, Atlantic and myself as chairman.

The response to our letter to Sections requesting the names of those who would be prepared to contribute time and effort to the attaining and to the preservation of reports, pictures and correspondence appropriate to the terms of reference was disappointing. Another appeal for support is in the offing; I am confident that there are many Members who could contribute greatly to this "preservation of our foundations".

Through the good offices of the Ontario Ministry of Natural Resources, we were able to obtain a video-tape interview with Dr. J.W.B. Sisam in June, 1988. Similar records of outstanding Canadian forestry endeavours are long overdue.

The Strategic Plan Discussion Paper of the CIF/IFC of December, 1987, identified four steps in a three year strategic plan. In this plan, which contains a summary of the SAF work in the same area, there is virtually nothing proposed with respect to recording the background of forestry in North America - much has already been lost, but there is much ready to be realized.

Anyone reading this report who can and will contribute, please contact me or a member of the National Committee.

\section{D.V. Love} Chairman

\section{Forest Science and Technology Board Annual Report - 1987-88}

Due to financial constraints and to the repositioning of FSTB as proposed in the strategic plan of the CIF/IFC, there has been only one meeting of the FSTB in 1987-88.

It was held in St. John's, Nfld., during the 1987 Annual Meeting. In addition to present members (MM. Mike Bonnor, Hamish Kimmins, Gerry Lapointe), chairmen of working groups were invited as well as members of the Executive Committee. This meeting focussed on the role of FSTB, its relationship with working groups, and linkages with the Executive Committee. The discussion provided input to the chairman for the strategic plan.

Few steps were nevertheless taken to improve communication and involvement of working groups in Institute's affairs. Chairmen of working groups now receive the same regular information from head office as the section officers: Forestry Update, Forestry Dialogue and Brochures. On the other hand, they were asked if they wish to contribute to specific issues of Forestry Dialogue and some were also asked to revise Brochures or position papers of the CIF/IFC. They also received drafts of the strategic plan.

In addition, the chairman of FSTB has been involved with the Algonquin Section and the Executive Director in the preparation of the symposium on Advances in Canadian Forest Research.

\section{Claude Godbout}

Chairman

August 3,1988

\section{Comité de la Science et Technologie Forestière Rapport annuel 1987-88}

Dû aux contraintes financières et au repositionnement du comité proposé dans le plan stratégique de l'IFC/CIF, il n'y a eu qu'une seule réunion du comité en 1987-88.

Elle a eu lieu à St-Jean, T.N., durant le Congrès Annuel 1987. En plus des membres actuels du comité (MM. Mike Bonnor, Hamish Kimmins, Gerry Lapointe), les présidents des groupes de travail y ont été invités tout comme des membres du comité exécutif. Cette réunion a permis de discuter sur le rôle du comité de la science et technologie forestière, ses relations avec les groupes de travail, et ses liens avec le comité exécutif. Le président du comité a utilisé les éléments de cette discussion dans le plan stratégique.

Néanmoins, des actions ont été initiées pour améliorer les communications et l'implication des groupes de travail dans les affaires de l'Institut. Les présidents des groupes de travail reçoivent maintenant la même information régulière du siège

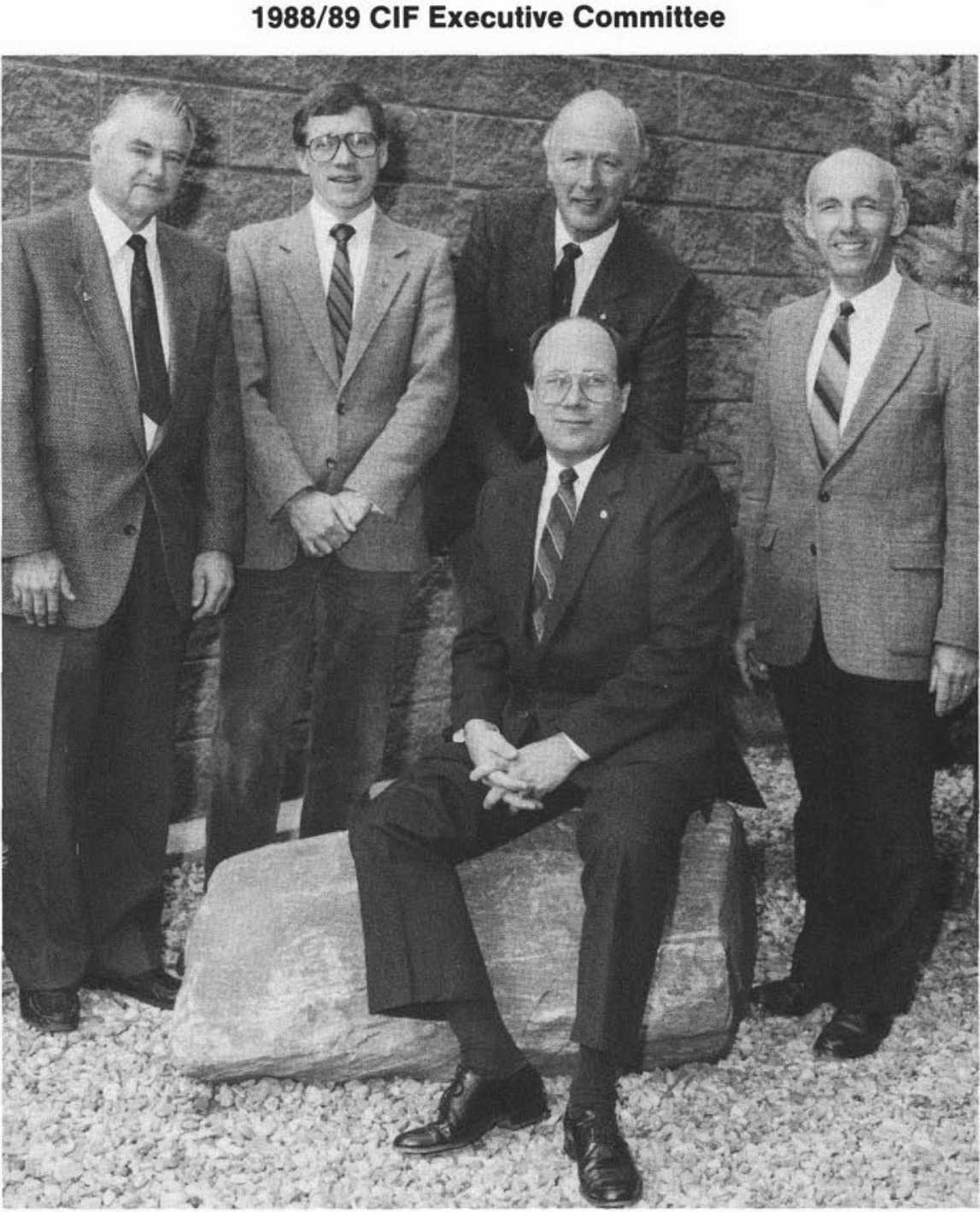

Standing ( $L$ to R): Jim Cayford (Executive Director), Peter Ackhurst (1st Vice-president), Jim Kayll (Past President), Harry Gairns (2nd Vice-president).

Sitting: Claude Godbout (President) 
social que les officiers des sections: Information forestière, Dialogue Forestier et les Brochures. Par ailleurs, on leur a demandé de contribuer à des numéros particuliers du Dialogue Forestier et quelques-uns vont revoir certaines Brochures ou énoncé de politique de I'IFC/CIF. Ils ont aussi reçu les différentes versions du plan stratégique.

De plus, le président du comité a été impliqué avec la section Algonquin et le directeur exécutif dans la préparation pour les 4 et 5 octobre 1988 du symposium sur les Réalisations en recherche forestière au Canada.

\section{Claude Godbout Président 3 août 1988}

\section{Forest Ecology Working Group (A) 1987-88 Annual Report}

The Working Group met in St. John's at the 1987 CIF/ICF Annual Meeting with the Forestry Education Working Group for a Joint Technical Session that consisted of a field trip to a nearby coastal forest. The 17 participants and 4 leaders (B.D. Titus, W.J. Meades, B.A. Roberts and A.U. Mallik) travelled $2 \mathrm{~km}$ north of St. John's to climb Sugarloaf Head, a prominant coastal landmark which offers an unparalleled view of Cape Spear and the rocky bluffs which mark the entrance to St. John's Harbour. The Head provided delegates with the unique opportunity of viewing at first hand coastal heathlands which are very similar in composition to those found in Europe, as well as the cline from heathland through to coastal forest. At stops along the way, delegates discussed the geology and soils of the area, heathland vegetation, the possible allelopathic effects of Kalmia angustifolia on black spruce growth and potential silvicultural solutions, successional dynamics of forest-heathland areas and the role of fire, and the management and local utilization of coastal forests. Copies of a handout prepared for the tour may be obtained from the Chairman.

There were no further activities this past year. Planning for the 1988 Annual Meeting in Prince Albert is complete, and planning has begun for the 1989 Annual Meeting in Kananaskis. Dr. Ian Corns (Northern Forestry Centre, C.F.S., Edmonton) is currently Vice-Chairman of the Working Group. Membership stood at 126 on 26 January, 1988.

Dr. B.D. Titus Chairman July 21,1988

\section{Economics and Policy Working Group (B) 1987-1988 Annual Report}

The working group held a joint technical meeting with the International Forestry working group at the 1987 meeting in St. John's, which included a presentation on "Environmental impact assessment of forest management practices in Canada' by Pat Duffy and Adrian van Frassen. For

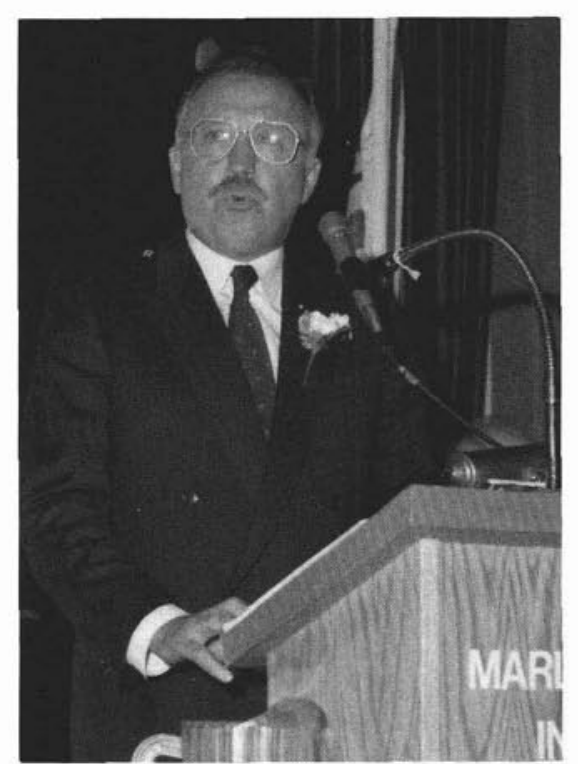

The new federal Minister of Forestry, the Hon. Gerry St. Germaine, addresses the Annual CIF Banquet.

the 1988 meeting in Prince Albert, speakers are lined up for a joint working group meeting on aspen. As well, a WG(B) meeting will feature a panel on "The Brundtland Commission Report and its implications to Canadian forestry" with Dr. J. Stan Rowe and Dale Stewart.

$W G(B)$ continued to encourage policy and economics articles for The Forestry Chronicle, resulting in an article on the new Quebec forest policy and other contributions. Requests for assistance were received from the Executive Committee but not from the Forest Science and Technology Board.

Vice-chairman Grant Milne attended meetings of the Canadian Association of Forest Economists, exploring linkages with $W G(B)$. It is hoped that this will lead to collaboration in the future.

The working group chairman participated in the CIF/IFC Strategic Planning Exercise throughout the year, the results of which will be reviewed at Prince Albert.

Grant Milne will take over from Pat Duffy as WG chairman at the Prince Albert meeting and he will count on the continued support and interest of WG members, Institute officers and members as well.

\section{Patrick Duffy} Chairman

\section{Forest Education Working Group (G) 1987-1988 Annual Report}

A successful joint meeting with the Forest Ecology Working Group was held in August at the 1987 CIF/IFC Annual Meeting in St. John's, Newfoundland. This involved a field trip, led by Dr. B.D. Titus, on the Avalon peninsula to view some of the plants and landscapes of the most easterly region in Canada. A short business meeting followed the field trip. The Newfoundland meeting theme was "Fore- stry Communications: The Essential Link", a subject discussed at the $1984 \mathrm{CIF}$ Annual Meeting in Quebec by the Forest Education Working Group in joint sessions with the Society of American Foresters. As such it was strongly involved with several resolutions that arose from the 1987 Annual Meeting on the topic of Communications. Namely, resolution 87.5, "Resolved that the CIF/IFC encourage all forestry faculties across Canada to maintain and improve the education of foresters in appropriate communications skills". Resolution 87.16, "Resolved that the CIF/IFC expand the mandate of the Forest Education Working Group to include communications and stimulate, guide and coordinate participation of the membership in effective communication of forestry issues among all those interested in the forest sector, including the public at large"; and 87.17, "Resolved that the CIF/IFC endorse and support the concept of an annual forum for information exchange that would include all those concerned with, and involved in, forestry communications and that the CIF/IFC be prepared to provide leadership, with other participants throughout the sector, in the realization of such an annual forum within the next year." The president of the FACT Committee, Glen Swant, is interested in developing more forestry awareness projects and is keen in forming a Public Awareness Working Group that could act as a think tank for initiating ideas in forestry awareness and stimulate more activity in this area. This topic could be discussed at the forthcoming business meeting of the Forest Education Working Group at the $\mathrm{CIF/IFC} \mathrm{Annual} \mathrm{Meeting} \mathrm{in} \mathrm{Prince} \mathrm{Albert} \mathrm{in}$ September.

\section{An Overview of Private Forestry in Saskatchewan}

In an effort to focus more attention on private land forestry the Working Group has organized a field trip to a demonstration woodlot near Prince Albert at the upcoming Annual Meeting on September 21 , with the cooperation of local, provincial and Canadian Forestry Service personnel. The topic of discussion will be the role of the joint Canada-Saskatchewan Forest Resource Development Agreement (FRDA) in advancing forestry practices and promoting the cooperative efforts of both governments and industry in the development of a woodlot extension program for the 350000 hectares of privately owned forest land in Saskatchewan. With the increased interest being shown by many provincial forestry departments in private forestry, it is a topic of growing importance for examination by the Forest Education Working Group. Currently priority is given to private forest management education in most forestry schools. How can this important concern for private forestry be pressed forward? It will hopefully be an interesting afternoon for the members of the Working Group who are able to attend the Prince Albert meeting.

A.R.C. Jones, R.P.F., ing f. 
Forest Pest Control Working Group (D) - 1987-1988

At the 1987 annual meeting of the CIF/ IFC, the forest pest control WG held a joint session with the forest management and the silviculture and tree improvement working groups to explore communication among the various forestry disciplines. Discussion at the session focused on information systems for planning and implementing forest management. The forest pest control WG invited Mr. J.M. Power to discuss decision support systems for the Forest Insect and Disease Survey of the Canadian Forestry Service and for pest management in general. His paper, together with the papers of the other speakers at the meeting, was published in volume 64 of The Forestry Chronicle.

Early in 1988 the past chairman (P. de Groot) tried to organize a joint session with other working groups. The attempt failed, partly because some working groups had already joined forces and could not accommodate our WG, and partly because some working groups failed to respond to the request. Because of the small size of the working group and the difficulty in attracting an audience when concurrent sessions are held, a separate working group session was not organized for the Prince Albert meeting.

Peter de Groot resigned as chairman of the working group in March of 1988 and Mr. E.T.N. Caldwell of the Forest Pest Management Institute, Canadian Forestry Service became the new chairman in May.

\section{E.T.N. Caldwell}

\section{Forest Hydrology Working Group (G) - 1987-1988 Annual Report}

The working group did not meet at the 1987 annual CIF meeting in St. John's because of low attendance. A meeting, however, is scheduled for the 1988 meeting, with a planned program of speakers from British Columbia, Ontario and Quebec. Topics to be presented include a forest hydrology sensitivity analysis for coastal B.C., the potential of forested peatland drainage for forest management, and a methodology for predicting water yield after forest harvesting.

Initial plans are in progress among working group members for adopting a common hydrologic model for use in Canada. The objective of this proposal is to adopt a model that can be used as a foundation for developing methodologies for evaluating hydrologic impacts of forestry. Contact person for those interested is Bob Swanson at the Northern Forestry Research Centre, Edmonton, Alberta.

\section{Dr. R.L. Rothwell} Chairman

\section{Forest Management Working Group} (J) - 1987-1988 Annual Report

\section{Program}

The Forest Management Working Group participated in Session I of the concurrent

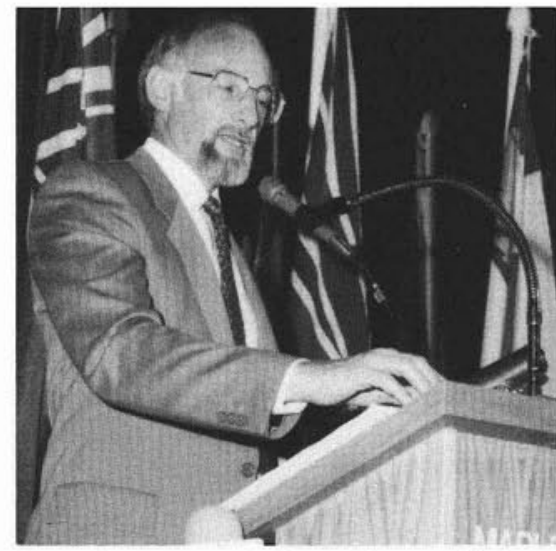

Doug Crossman, Assistant Deputy Minister, Saskatchewan Department of Parks, Recreation and Culture addresses the Monday Luncheon at the CIF Annual Meeting in Prince Albert.

technical sessions during the 1987 Annual Meeting. We selected as our theme, "Planning the New Forest: Information Systems". We viewed this as an aspect of the convention theme, "Forestry Communications - The Essential Link". Dr. Gordon Baskerville spoke on behalf of the Forest Management Working Group. I served as moderator for the session and coordinated the preparation of speakers' papers for publication in The Forestry Chronicle (April, 1988).

For the 1988 Annual Meeting, the Working Group is joining forces with the Ecology, Economics and Policy, and Silviculture and Tree Improvement Working Groups to present a joint technical session on the theme, "Managing for Aspen - A Shared Responsibility". Again, we tried to select a theme that complemented the convention theme.

The Working Group has agreed to prepare a draft revision of the CIF brochure, "How Should Canada's Forests Be Managed?" The due date is November 1, 1988.

\section{Membership}

In 1987-88, 191 CIF members indicated the Forest Management Working Group as their first choice and 176 indicated the Working Group as their second choice, compared with 186 and 161 in 1986-87.

\section{Executive}

My term of office began in January, 1985. C.A. Benson agreed in February, 1988 to serve as Vice-Chairman. He will become Working Group Chairman on January 1, 1989.

B.D. Haddon, R.P.F. Chairman

Forest Measurement Working Group (K) - 1987-1988 Annual Report

In December, 1987 the Chairman of the Forest Measurement Working Group resigned. The position is now vacant.

J.H. Cayford, R.P.F. July 7,1988
Silviculture and Tree Improvement Working Group (L) - 1987-1988 Annual Report

At the 1987 Annual Meeting held in St. John's, Newfoundland, a joint technical session was held with two other working groups - Forest Pest Control and Forest Management - to explore another aspect of forestry communications that was that meeting's theme. The joint presentation was focused on information systems for planning (and implementing) management in the new forest. The Silviculture and Tree Improvement working group's speaker was Dr. K.J. Mitchell, Research Branch, BC Ministry of Forests and Lands whose talk was entitled "SYLVER: Modeling the imipact of Silviculture on yield, lumber value and economic return". This paper, and the two others, were published in the April, 1988 issue of The Forestry Chronicle.

Group delegates at the St. John's meeting agreed to organize a similar combined technical session for the 1988 meeting to be held in Prince Albert, Saskatchewan. Forest Ecology, Forest Management, Forest Economics and Policy will join with Silviculture and Tree Improvement to present a Joint Technical Session on "Managing for Aspen - a shared responsibility". An excellent group of speakers will address this topical subject and the papers will be published in a future issue of The Forestry Chronicle.

As your chairman over the past two years, my strategy has been to cooperate with other working groups to come up with a good, technical half-day session that complements the program theme selected for the Annual Meeting. This was done in 1986 at Victoria, in 1987 in St. John's and will be followed this year in Prince Albert as noted above. As was done in 1987, I intend to have these papers published for the benefit of those members who could not attend the Annual Meeting. My term of office will end this year and Jim Richardson, Canadian Forestry Service, Ottawa will assume the chair at the Annual Meeting in Prince Albert.

\section{J.T. Arnott, R.P.F.}

\section{International Forestry Working Group (O) - 1987-1988 Annual Report}

President: Cameron Clarke - CFS Ottawa

Vice President: Michel Laverdière CIDA Ottawa

Secretary: Bill Clarke - Newfoundland Forest Service, Roddickton

One informal meeting was held in Ottawa in October 1988 to get the working group started. Two other meetings were held, one in Vancouver in January 1988 and one in Hull in March 1988. It was agreed that the minutes of each meeting would be sent to all past presidents of the working group as well as the executive director of the CIF. The executive director will also be invited to all international forestry working group meetings. 
The main thrust of the working group at present will be towards the support and creation of an International Forestry Centre of Excellence in Vancouver, British Columbia. We hope that this centre will serve and be controlled by industry. The incumbent members of the working group believe that we must do what we can to support industry at a time when world competition in forest equipment and products is fierce. A centre of excellence will provide a focal point and coordinating centre for intelligence gathering, biotechnology, silviculture, protection, logging, wood products, and policy, trade, taxation, management and regulation. The prime objective is to make Canada more competitive.

The selection of International Forestry Award plaques will be made in July.

The IFWG meeting at Hampco 88 will include presentations on the following: the IFWG, the International Forestry Centre of Excellence, South East Asia, and International competition in the pulp and paper industry.

A call to Canadian foresters working abroad was made through The Forestry Chronicle for articles on their work. We think this is a relevant and practical approach to keeping abreast on the international forestry scene.

A follow up note to the executive director was sent regarding a bilingual Forestry Chronicle. One final meeting will be held by the IFWG before Hampco 88 .

\section{C.R. Clarke} President

\section{Report on the Canadian Journal of Forest Research}

The Canadian Journal of Forest Research is one of 13 journals published by the National Research Council. Now in its 18 th year, the Journal continues to grow in popularity. In 1987, 371 manuscripts were received. So far in 1988, submissions are up over $25 \%$ over the same period in 1987 and close to double the number received five years ago. 211 Articles, 29 notes, two reviews, three discussions and one rapid communication were published in 1630 pages and 12 issues in 1987. We began publishing as a quarterly in 1971 , went bi-monthly in 1983, and began publishing monthly in 1987. In the first eight issues published in 1988, 153 Articles, 29 notes, one review, and one discussion were published in 1096 pages.

About $40 \%$ of the manuscripts currently received originate from authors in Canada, $50 \%$ from those in the U.S. and $10 \%$ from scientists in other countries. Between 60 and $65 \%$ of the manuscripts received are published.

A special issue, "Roots in Forest Soils: Biology and Symbioses," was published in the August 1987 issue. Other special issues will be forthcoming. Three Reviews were published over the past year. In July of 1987, Guillermo Mendoza's review, "Goal programming formulations and extensions: an overview and analysis," was published. In November, Jim Harrington's "Climatic change: a review of causes," was published. In the August 1988 issue appeared "Land base models for forest resource supply analysis: a critical review," by Peter Parks and Ralph Alig. Authors with ideas for review papers and readers with suggestions for special issues should contact the Editor.

The Canadian Journal of Forest Research continues to rank second among 13 forestry and forest products journals (just barely behind a European wood science journal) on the basis of the average frequency of citation for our articles by other papers (1986 SCI Journal Citation Reports). This continuing high ranking reflects the quality of manuscripts received and published and the Journal's international audience. With this high international reputation, the Canadian Journal of Forest Research expects to continue to attract the best manuscripts of the best Canadian and international scientists. In particular, we encourage the submission of manuscripts in novel and frontier areas of basic forest research so that we can continue to serve our readers in an increasingly competitive forestry journal market.
Total number of subscriptions is now close to 1000 , which is gratifying when many journals are seeing declining numbers of subscriptions. In addition to the usual promotional activities to recruit new subscribers, we have been exchanging advertisements for the Journal with those of some of our competitors and with Forestry Abstracts. The regular appearance of our tables of contents in The Forestry Chronicle has kept the contents of the Journal before CIF members and hopefully will attract more subscribers at the special society rate.

The Journal's success is heavily dependent upon the volunteer efforts of many referees and the members of the Editorial Board. Current Associate Editors include BURT BARNES and CRAIG LORIMER (ecology), GORDON BASKERVILLE (modelling, biomass, general biology), BILL BLOOMBERG and PRITAM SINGH (pathology), TOM BURK (growth and yield, mensuration), RENE DOUCET (stand tending, silviculture), DAVE FAYLE (morphology, crown and root form), NEIL FOSTER and IAN MORRISON (nutrient cycling, air pollution, acid rain), DOUG GOLDING (hydrology), CLAYTON KEITH (wood properties, wood technology), DAN KEPPIE (wildlife biology), DON LESTER (genetics, tree improvement), TONY LITTLE (physiology), GLENN MANNING (economics), IAN METHVEN (fire), BILL REIFSNYDER (climatology), ARTHUR RETNAKARAN (entomology), STEVE ROSS (reproductive physiology), RON SEDEROFF (molecular genetics, genetic engineering, micropropagation, tissue culture), BOB SWANSON (water relations), and BILL WARREN (statistics, sampling). Former Associate Editors ROY WHITNEY, DON DURZAN and BOB KENNEDY retired during the past year after many years of excellent service. Coeditor BERNARD BERNIER handles all the manuscripts written in French. All of the referees and Associate Editors have our thanks for their excellent and tireless service.

Bruce P. Dancik Editor

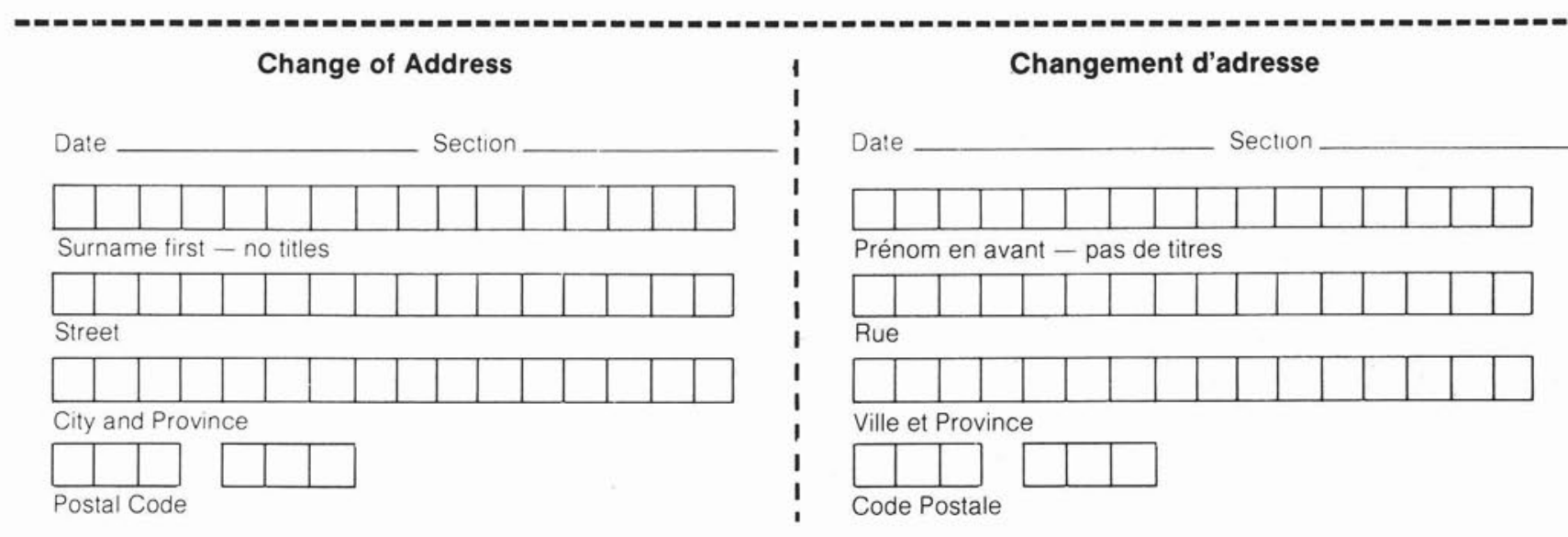




\section{Canadian Institute of Forestry/Institut Forestier du Canada 80th Annual General Meeting \\ September 19 and 22, 1988 \\ Prince Albert, Saskatchewan}

MINUTES

1.

1.1 President Kayll opened the meeting at 10:05 hrs.

1.2 It was noted that L. Riley is Chairman of the Resolutions Committee and would welcome resolutions. Other committee members are Jim Richardson and René Doucet.

\section{Deceased Members}

The President read the names of members deceased since the last Annual Meeting and asked delegates to stand and observe a moment of silence in their memory. They are:

$\begin{array}{ll}\begin{array}{l}\text { W.E. Steele } \\ \text { K.M. MacKay } \\ (1986)\end{array} & \begin{array}{l}\text { Southern Ontario } \\ \text { Nova Scotia }\end{array} \\ \text { E.F. Anderson } & \text { Southern Ontario } \\ \text { A. Webster } & \text { Maritime } \\ \text { K. Smith } & \text { Maritime } \\ \text { G.P. Thomas } & \text { Vancouver Island } \\ \text { K. MacAuley } & \text { Saskatchewan } \\ \text { D.E. Nickerson } & \text { Newfoundland } \\ & \text { (Fellow) } \\ \text { G.W. Phipps } & \text { Southern Ont. } \\ \text { R.R. Lejeune } & \text { (Past Pres.) } \\ & \text { Vancouver Island } \\ \text { H.D. Dagg } & \text { (Fellow) } \\ \text { W.H. Nasi } & \text { Vancouver Island } \\ \text { G. Wright } & \text { Nova Scotia } \\ \text { L.G. Davis } & \text { Central Ontario } \\ \text { A.M. Miller } & \text { Maritime } \\ & \text { Vancouver }\end{array}$

3. Approval of Minutes of 79th Annual General Meeting

The Minutes of the 79th Annual General Meeting were published in The Forestry Chronicle, October 1987 issue.

MOTION G88-1 (P.J.B. Duffy, C. John)

THAT the minutes of the 79th General Meeting be approved

Carried

\section{$4 . \quad$ Officers' Reports}

\subsection{President's Repor}

The President presented his report. It will be published

MOTION G88-2 (D.R. Redmond, W.G. Burch)

THAT the report be accepted.

Carried

\subsection{Executive Director's Report}

The Executive Director summarized his report. It will be published.

MOTION G88-3 (J. Beck, C.H. Gairns)

THAT the report be accepted.

\subsection{Forestry Chronicle Officers}

The reports by the Editor, I.C.M. Place, and the Production Manager, D.R. Red- mond were summarized by D.R. Redmond.

Reports will be published

MOTION G88-4 (M. Williams, P. Aird)

THAT the reports be accepted.

Carried

The lack of coverage on technology schools was noted by one member

P. Aird emphasized the fine job being carried out by the Editor and Production Manager.

\subsection{Report on Committees}

The President summarized the reports of the following committees:

Board of Examiners, Membership, By-laws, Nominating, Resolutions, Publications Policy and of the Editor of the Canadian Journal of Forest Research. Reports will be published.

MOTION G88-5 (A. Furniss, G.J. Garner)

THAT the reports be accepted.

Carried

5. Report of Chairman, Forest Science and Technology Board

Godbout summarized the report. It will be published.

MOTION G88-6 (J. Heidt, A. Wynia)

THAT the report be accepted.

Carried

\section{Report of President, Forestry} Awareness in Canada Trust

Kayll summarized the report, prepared by Swant, President, FACT. It will be published. MOTION G88-7 (M. Williams, F. Von Althen)

THAT the report be accepted.

Carried

\section{Presentation of Awards}

7.1 Canadian Forestry Achievement Award

G. Paille will receive the award at the banquet.

7.2 Canadian Forestry Scientific Achievement Award

F. Von Althon will receive the award at the banquet.

7.3 International Forestry Achievement Award

R.W. Roberts will receive the award at the banquet.

\subsection{Fellow Members}

D.V. Love, Southern Ontario Section has been elected by the Board of Directors to Fellow Member status. His C.V. was summarized by the President.

\subsection{Special Award}

Cariboo Section received a specia award for the Willow River Demonstration Forest.

The award was presented to Director John Elmslie by President Kayll.

\subsection{Gold Medal Recipients}

Six gold medals were presented during the year to members of the graduating classes of the forestry faculties. The recipients were Jean-Martin Lussier, Laval (Dec 1987); F.E. Oberle, UNB; R. Prins, U Alta; Naomi Donat, $U$ of T; R.J. Robazza, UBC; and Scott Mitchell, Lakehead.

\subsection{Schlich Memorial Prize}

The recipient is from the University of British Columbia.

\subsection{Golden Year Certificates}

The names for 1987 are as follows: A Bickerstaff, D.M. Dyer, S.M. Golder, R.S. Hyslop, P. Morley, Wm. Thom. R. Hyslop was present to receive his award.

\subsection{Membership Prize}

The membership prize for obtaining the greatest percentage increase in membership through recruiting was presented to $R$. Doucet, Director Orleans Section.

\subsection{Rings}

During the year, the CIF/IFC presented a total of 304 foresters rings to graduating students of six forestry faculties.

President Kayll acknowledged the presence of Past Presidents Burch, Carrow, Cayford, Garner, Giles, Nordin, Paillé, Redmond and Toovey, and Honorary Member G. Bruce.

\section{Strategic Plan - Introduction}

P. Ackhurst outlined the background leading to the development of the draft strategic plan, June 1988. He reported on the Director's workshop and noted that it was approved in principle subject to the incorporation of certain amendments. The draft will be presented for approval in principle during the Thursday session.

\section{National Forestry Accreditation Project - Introduction}

V.J. Nordin presented an introduction to the National Forestry Accreditation Project. The presentation emphasized the background leading to the project, and outlined the benefits of a national system for forestry accreditation and reviewed the current status of implementation. 
10.

Finance

10.1 Finance Committee's Report

J.H. Cayford summarized the Finance

Committee report. It will be published.

MOTION G88-8 (J.H. Cayford, M. Williams)

THAT the report be accepted.

Carried

\subsection{Auditor's Report}

J.H. Cayford summarized the Auditor's report. It will be published. Miscellaneous expenditures include National Accreditation Project $\$ 2000$ Strategic Task Force $\$ 978$, Moving Expenses for ED $\$ 7500$, Memberships and Subscriptions \$1 108, Printing $\$ 5567$, and Bank Charges $\$ 400$. MOTION G88-9 (J.H. Cayford, D. Couch) THAT the report be accepted.

Carried

10.3 Budget for 1988-89

J.H. Cayford explained the budget. It will be published.

MOTION G88-10 (J.H. Cayford, M. Little)

THAT the budget be approved

Carried

10.4 Appointment of Auditor

MOTION G88-11 (J.H. Cayford, J.W. Toovey)

THAT Cook, Perry, Sewell and Co. be appointed as auditors for CIF/IFC for 198889 provided that satisfactory arrangements can be made and failing such that the Executive Committee make other arrangements.

Carried

\section{Rules and Regulations}

\subsection{Rule 3.1 National Dues}

MOTION G88-12 (D.R. Redmond, D. Couch)

THAT Rule 3.1 be amended as follows: National Dues. National dues for all classes of members will be recommended annually by the Board of Directors and ratified or amended at the next Annual Meeting. They will be published in The Forestry Chronicle.

Carried

\subsection{Rule 3.5 Subscriptions}

MOTION G88-13 (J. Beck, M. Williams)

THAT Rule 3.5 be amended as follows: Subscriptions. Annual subscription rates to The Forestry Chronicle will be recommended annually by the Board of Directors and ratified or amended at the next Annual Meeting. They will be published in The Forestry Chronicle.

Carried

\subsection{Rule 4.3.6 International Forestry Achievement Award}

MOTION G88-14 (J.O. Smith, G.A Steneker)

THAT Rule 4.3 .6 be approved.

Each year nominations submitted on or before May 1 are to be considered by the Executive Committee, in consultation with the International Forestry Working Group, for the International Forestry Achievement
Award. The Award to be presented annually or from time to time shall consist of an appropriate Award and Citation.

Carried

\subsection{National Dues 1989-90}

A proposal for 1989-90 dues was presented by J.H. Cayford.

MOTION G88-15 (M. Williams, J. Heidt)

THAT the dues for $1989-90$ be set as follows:

\section{CIF/IFC DUES 1989-1990}

\section{Active Membership}

1 st and 2 nd year after graduation (grad 1989, grad 1988)

Other new members for first year

Married or equivalent, second member only

All other active members

$\$ 73.00$

$\$ 73.00$

$\$ 73.00$

$\$ 103.00$

\section{Affiliate Membership}

1 st and 2nd year after graduation (grad 1989, grad 1988)

Other new members for first year

Married or equivalent, second member only

All other affiliate members

$\$ 73.00$

$\$ 73.00$

$\$ 73.00$

$\$ 97.00$

\section{Other Memberships}

Members having retired status who wish to receive The Forestry Chronicle

Members having retired status who do not wish to receive The Forestry Chronicle

Student Members

Sustaining Individuals (CIF Members)

Sustaining Corporate

Carried

\subsection{Forestry Chronicle Subscription} Rates - 1990

A proposal for 1990 Forestry Chronicle subscription rates was presented by J.H. Cayford.

MOTION G88-16 (D.R. Redmond, W.K. Fullerton)

THAT the 1990 Forestry Chronicle subscription rates be set as follows:

\section{Inside Canada}

Libraries and other multi-users $\$ 71.00$ Single Users

$\$ 65.00$

\section{Outside Canada}

Libraries and other multi-users $\$ 87.00$

Single Users

$\$ 76.00$

Price of Single Issues:

- Not more than two years old $1 / 5$ of annual subscription rate

- More than two years old \$15.00 Can postpaid to any destination.

Carried
12. Staffing

The President announced the appointments by the Board of Directors of Dr. I.C.M. Place as Editor of The Forestry Chronicle and Dr. D.R. Redmond, as Production Manager of The Forestry Chronicle, for calendar year 1989 .

13.

\section{Annual Meetings}

The President reported that the locations of Annual Meetings have been approved as follows:

$$
\begin{aligned}
& 1992 \text { - Vancouver Section } \\
& 1991 \text { - Toronto, Ontario } \\
& 1990 \text { - Fredericton, New Brunswick } \\
& 1989 \text { - Kananaskis Country, } \\
& \text { Alberta }
\end{aligned}
$$

\section{CIF/IFC Strategic Plan Discussions}

P. Ackhurst summarized the status of the plan. He noted that the document is a rough draft that will be edited subsequent to the meeting. The plan is in two parts (a) mission and activities, (b) strategic directions. Strategic directions are outlined in the plan - Annual Meetings, Forest Science and Technology Board, Linkages, Accreditation, Communications, Organization, Directors Meeting, Three-Year Plan and Membership.

MOTION G88-17 (P.J.B. Duffy, J.W Toovey)

THAT the Strategic Plan be approved in principle.

Discussion included the need to define the "Forestry Constituency, distribution of Forestry Dialogue Forestier, membership categories (especially the elimination of affiliate members), accreditation and RPF linkages, respective roles of CIF/IFC and provincial RPFs, linkages with existing technical forestry associations, the lack of recognition of fellowship and esprit de corps within the mission statement, and FSTB.

Carried

15.

\section{Resolutions}

L.F. Riley, Chairman of the Resolutions Committee, outlined the procedure for considering resolutions and chaired the meeting during their presentation and consideration. Members of the committee were R. Doucet and J. Richardson.

\section{Resolution 88.1 (J.A. Dunster SO, S. Rose SO)}

WHEREAS The CIF/IFC has adopted the spirit and intent of the World Conservation Strategy, the report of the World Commission on Environment and Development (The Brundtland Report), and a National Forest Sector Strategy for Canada, all of which recognize the need for greater cooperative effort between developers and conservationists; and

WHEREAS The CIF/IFC is a national forestry organization which promotes good management of forests and their associated resources; and 
WHEREAS The Nature Conservancy of Canada is now in the process of establishing publicly accessible computerized data bases of factual information on many different aspects of the biophysical environment; and

WHEREAS The CIF/IFC actively seeks to promote and foster better communications and understanding among all users of the forests and associated lands; therefore

BE IT RESOLVED that the CIF/IFC express to the Nature Conservancy of Canada its support for the establishment and use of the Conservancy's data bases.

MOTION to amend (A. Wynia SO, P. Brennan $\mathrm{CO}$ )

THAT the last paragraph be amended to read "Be it resolved that the CIF/IFC Executive Committee consider expressing to the Nature Conservancy of Canada its support for the establishment and use of the Conservancy's data bases".

Carried

Vote to adopt the amended resolution

\section{Carried}

\section{Resolution 88.2 (R.J. Bourchier OV, R. Baerg OV)}

WHEREAS Canadian forestry research funding, in real terms, has not increased since 1968 and is only about $0.7 \%$ of forest products sales compared to $1.5 \%$ in the United States and $1.75 \%$ in Sweden; and

WHEREAS Annual investment in forest management now stands at 1.5 billion dollars and has been growing at an annual rate of about $6 \%$, in real terms, during the 1980's; and

WHEREAS It is of the utmost importance to do everything possible to ensure that the maximum benefits are obtained from these investments; and

WHEREAS The International Union of Forestry Research Organizations will hold its 19th World Congress in Montreal from August 5-11, 1990 and this event will generate public awareness of the importance of forestry and forestry research; therefore

BE IT RESOLVED that the CIF/IFC use every opportunity that arises during the period up to and including the 1990 Congress to publicize the importance of forestry research to the future of all Canadians and to urge policy makers in governments and industry to increase their support for forestry research.

MOTION to amend (G.A. Steneker OV, J.W. Giles SO)

THAT the last paragraph be amended to include the word "particularly" after the phrase "use every opportunity that arises".

Carried

Vote to adopt the amended resolution.

Carried

\section{Resolution 88.3 (P.J. Murphy RM, P. Aird SO)}

WHEREAS The Right Honourable Brian Mulroney has elevated forestry to full department status and has appointed a Minister of Forestry; and

WHEREAS The CIF/IFC has long advocated this important step; therefore

BE IT RESOLVED That the President of the CIF/IFC write to Mr. Mulroney.

To thank him for giving the forestry sector the recognition it has long warranted, and

To strongly urge him to give the new department and minister the resources and political support they need, and

To offer the co-operation and advice of the CIF/IFC in developing programs to meet the most urgent needs of the forestry sector, and

BE IT FURTHER RESOLVED That the President of the CIF/IFC write to the Honourable Gerald St. Germain.

To congratulate him on appointment, and

To offer the good offices of the CIF/IFC in helping to define the expanded role and programs for forestry to be addressed by the new department.

Carried

\section{Resolution 88.4 (P. Aird SO, P.J. Murphy RM)}

WHEREAS The Honourable Gerald Merrithew has been elevated to the position of Minister of Veterans Affairs, and

WHEREAS He has served diligently and well as the first Minister of State (Forestry and Mines), therefore

BE IT RESOLVED that the President of the CIF/IFC send a letter of appreciation to the Honourable Gerald Merrithew acknowledging with thanks his fine leadership and effort, which have served the national forest sector well, and which have also clearly demonstrated the need for full ministerial representation for forestry at the federa cabinet level.

Carried

\section{Resolution 88.3 (R. Slaco PA, B. MacArthur VA)}

WHEREAS The activities of the CIF/IFC are directed at improving the stewardship of forest resources for the benefit of society; and

WHEREAS The beneficiaries of those efforts are the general public and the industrial forest community; therefore

BE IT RESOLVED that the CIF/IFC Executive Committee and Section Chairmen develop a strategy to aggressively seek financial support from all levels of government and industry to assist the CIF/ IFC in undertaking these activities.

Defeated

\section{Resolution 88.6 (P.J.B. Duffy VA, A.L. Whidden NS)}

WHEREAS The CIF/IFC Strategic Plan has been approved in principle following development by a Task Force and amendment by the Board of Directors with limited input by other forestry groups and associations; and

WHEREAS The CIF/IFC is about to move ahead, guided by priorities in the plan which are to be renewed annually on a three-year planning time frame; and

WHEREAS The CIF/IFC now has a valuable opportunity to inform a wide range of groups and associations on the CIF/IFC organization, purpose and priorities, and at the same time to receive comments from parties with diverse interests and views on Canadian forestry, such as environmental, wilderness, recreational, educational, professional, political and media organizations; therefore

BE IT RESOLVED that the CIF/IFC circulate the Strategic Plan in the next year to a large number of interested parties for information and comment.

Withdrawn

\section{Resolution 88.7 (C.H. Geale RM, P.J. Murphy RM)}

WHEREAS University forestry students represent the new lifeblood of the profession; and

WHEREAS It is essential to bring students into the mainstream of forestry as quickly as possible; and

WHEREAS The CIF/IFC wishes to encourage student membership and involvement of new forestry graduates; and

WHEREAS The Annual General Meetings of the CIF/IFC present an excellent environment in which to convey the dynamic nature of the forestry profession and to demonstrate that the profession is an exciting one in which to be a participant; and

WHEREAS These meetings afford opportunities to encourage student involvement and membership; therefore

BE IT RESOLVED that the CIF/IFC and the HAMPCOs undertake to arrange funding support to bring a student representative from each of the university forestry schools to the Annual General Meetings of the CIF/IFC.

Carried

\section{Resolution 88.8 (P.J.B. Duffy VA, C.H. Geale RM)}

WHEREAS The program and duration of the CIF/IFC Annual Meeting and ancillary activities has been relatively fixed over the past decade; and

WHEREAS An ever increasing number of meetings and activities of internal CIF/IFC bodies and external associated bodies must be accommodated within the overall Annual Meeting unbrella; and

WHEREAS The schedule is already so crowded that meetings, presentations, activities and important discussions, including the technical and scientific content of the program, are often rushed, overlapping and/or incomplete thereby reducing their effectiveness and value; therefore

BE IT RESOLVED that the Executive Committee arrange for a review, of past performance, productivity and social success of Annual General Meetings and ancillary activities, to be completed by the 1989 Annual General Meeting, with a view 
to recommending means to improve the overall meeting structure and organization including, specifically, the length of the meeting, and communications and consultation between the HAMPCO planners and all internal and external bodies involved.

Carried

Resolution 88.9 (J.W. Toovey VA, J. Hermelin MR)

WHEREAS Private woodlots make a significant contribution to the Canadian economy; and

WHEREAS Private woodlots have the potential to increase this contribution therefore

BE IT RESOLVED that the CIF/IFC recognize this contribution and the efforts being made to develop organizations, policies and programs to maintain and increase this contribution; and

BE IT FURTHER RESOLVED that the $\mathrm{CIF/IFC} \mathrm{support} \mathrm{activities} \mathrm{in} \mathrm{this} \mathrm{field} \mathrm{and}$ collaborate with provincial and national agencies and groups involved in the private woodlot sector to provide professional support to the benefit of the Canadian private woodlot sector, the Canadian forestry sector and the Canadian economy as a whole.

Carried

\section{Resolution 88.10 (J. Heidt RM, R.} Newstead RM)

WHEREAS Forestry is Canada's leading manufacturing and export industry; and

WHEREAS Canada's forests are important for timber production, environmental protection and the production of non-timber goods and services; and

WHEREAS Recent initiatives in strategic planning for the forest sector, as repre- sented by "A National Forest Sector Strategy for Canada" developed by the Canadian Council of Forest Ministers, are a positive beginning; therefore

BE IT RESOLVED that the CIF/IFC continue its efforts to persuade both national and provincial levels of government to refine and/or develop strategic plans for the forest sector that provide specific goals and realistic as well as achievable targets for the management of the forest land base. It is essential that these strategic plans recognize the importance of forests for wood production, environmental protection and the production of non-timber goods and services

Carried

Resolution 88.11 (F.W. Von Althen CO, J.M. Powell RM)

WHEREAS The national Executive of the CIF/IFC has acted on behalf of the combined membership over the past year; therefore

BE IT RESOLVED that the members of the CIF/IFC at the 80th Annual Meeting ratify, sanction and confirm all acts, covenants and proceedings made, taken or entered into on their behalf by the Board of Directors and by the Executive Committee during the past year.

Carried

\section{Resolution 88.12 (B. Haddon OV, B. Titus ND)}

WHEREAS The 1988 Annual Meeting of the CIF/IFC has considered in detail the matter of sharing responsibility for the management of Canada's forest resources and has contributed strongly to the betterment of understanding of the need for the sharing of this responsibility; and
WHEREAS This meeting of the CIF/IFC has contributed excellent intellectual stimulation and social interaction, therefore

BE IT RESOLVED That the delegates to this meeting applaud and heartily thank the members of the Saskatchewan Section and of HAMPCO ' 88 for planning and conducting an exceptional event in the resourcerich and beautiful province of Saskatchewan.

Carried

President Kayll called for a round of applause for the members of the Resolution Committee.

16.

Other Business

None.

17.

\section{New Officers}

President Kayll introduced the new officers for 1988-89. He thanked the Executive Committee for their help and Past President J.R. Carrow for his contribution. He welcomed C.H. Gairns as Second VicePresident, P. Ackhurst as First VicePresident and C. Godbout as President. He passed the gavel to Godbout. C. Godbout thanked J. Kayll for his contributions as President.

On behalf of HAMPCO '88 J.A. Benson made a presentation to members of the executive.

18.

\section{Adjournment}

President Godbout adjourned the 80th Annual Meeting at 11:40 hours.

J.H. Cayford September 27, 1988

Membership Dues 1988-1989

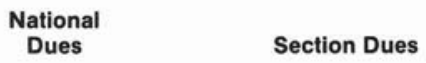

\begin{tabular}{|c|c|}
\hline \\
\hline $\begin{array}{l}\text { Active Membership } \\
\text { 1st and 2nd year after graduation } \\
\text { grad 1987, grad 1986) }\end{array}$ & $\$ 70.00$ \\
\hline Other new Active Members 1 st year & $\$ 70.00$ \\
\hline Married or equivalent, second member only & $\$ 70.00$ \\
\hline All other Active Members & $\$ 98.00$ \\
\hline $\begin{array}{l}\text { Affiliate Membership } \\
1 \text { st and } 2 \text { nd year after graduation }\end{array}$ & \\
\hline Other new Affiliate Memhers 1st vear & $\$ 70.00$ \\
\hline Other new Affiliate Members 1st year & $\$ 70.00$ \\
\hline Married or equivalent, second member only & $\$ 70.00$ \\
\hline All other Affiliate Members & $\$ 92.00$ \\
\hline $\begin{array}{l}\text { Members with Retired Status receiving } \\
\text { The Forestry Chronicle }\end{array}$ & $\$ 29.00$ \\
\hline $\begin{array}{l}\text { Members with Retired Status not receiving } \\
\text { The Forestry Chronicle }\end{array}$ & $\$ 00.00$ \\
\hline $\begin{array}{l}\text { Student Members } \\
\text { Sustaining Members (CIF) } \\
\text { Sustaining Members (Other) }\end{array}$ & $\begin{array}{l}\$ 29.00 \\
\$ 30.00 \\
\$ 200.00\end{array}$ \\
\hline
\end{tabular}

The Institute year runs from July 1 to June 30. Applications dated after January 1 will be charged half dues for that Institute year. Applications dated after April 1 will be charged no dues for that Institute year.

Section dues are in addition and range from $\$ 5.00$ to $\$ 20.00$ 